\title{
Seismic Proofing Capability of the Accumulated Semiactive Hydraulic Damper as an Active Interaction Control Device with Predictive Control
}

\author{
Ming-Hsiang Shih ${ }^{1}$ and Wen-Pei Sung ${ }^{2}$ \\ ${ }^{1}$ Department of Civil Engineering, National Chi-Nan University, Puli, Nantou 545, Taiwan \\ ${ }^{2}$ Department of Landscape Architecture, Integrated Research Center for Green Living Technologies, \\ National Chin-Yi University of Technology, Taichung 41170, Taiwan \\ Correspondence should be addressed to Wen-Pei Sung; wps@ncut.edu.tw
}

Received 4 March 2016; Revised 22 May 2016; Accepted 26 May 2016

Academic Editor: Nicola Caterino

Copyright (c) 2016 M.-H. Shih and W.-P. Sung. This is an open access article distributed under the Creative Commons Attribution License, which permits unrestricted use, distribution, and reproduction in any medium, provided the original work is properly cited.

\begin{abstract}
The intensity of natural disasters has increased recently, causing buildings' damages which need to be reinforced to prevent their destruction. To improve the seismic proofing capability of Accumulated Semiactive Hydraulic Damper, it is converted to an Active Interaction Control device and synchronous control and predictive control methods are proposed. The full-scale shaking table test is used to test and verify the seismic proofing capability of the proposed AIC with these control methods. This study examines the shock absorption of test structure under excitation by external forces, influences of prediction time, stiffness of the auxiliary structure, synchronous switching, and asynchronous switching on the control effects, and the influence of control locations of test structure on the control effects of the proposed AIC. Test results show that, for the proposed AIC with synchronous control and predictive control of $0.10 \sim 0.13$ seconds, the displacement reduction ratios are greater than $71 \%$, the average acceleration reduction ratios are, respectively, $36.2 \%$ and $36.9 \%$, at the 1st and 2 nd floors, and the average base shear reduction ratio is $29.6 \%$. The proposed AIC with suitable stiffeners for the auxiliary structure at each floor with synchronous control and predictive control provide high reliability and practicability for seismic proofing of buildings.
\end{abstract}

\section{Introduction}

Recently, strong earthquakes have caused great damage and loss of life. The Indian Ocean earthquake of 2004 caused widespread damage. In Sumatra Indonesia, the earthquake had a magnitude of 9.0 on the Richter scale (M 9.0), and the resulting South Asian tsunami killed more than 200,000 people. In 2008, the Wenchuan earthquake (M 8.0) struck along the Longmenshan Fault, a thrust structure along the border of the Indo-Australian Plate and Eurasian Plate. In 2011, an earthquake of the shore of Japan (M 9.0) caused a 10-meter-high tsunami that carried water into coastal areas, washing away buildings and leaving more than twenty thousand people dead or missing. In 2013, a strong earthquake in Pakistan (M 7.7) left 825 people dead and more than 700 injured. In 2015, an earthquake in Nepal (M 7.8) killed more than 7,600 people. An aftershock in May 2015 (M 7.3) caused numerous casualties. In January 2016, an earthquake with a Richter magnitude of 6.8 caused widespread damage in India and surrounding countries.

Taiwan, which is located on the Ring of Fire at the junction of the Eurasian Plate and the Philippine Sea Plate, has numerous earthquakes every year. In 1999, an earthquake with a Richter magnitude of 7.3 occurred in the vicinity of the Chelungpu Fault, which stretches for hundreds of kilometers under buildings and bridges. In February 2016, the Meinong earthquake (M 6.5) collapsed multiple buildings in southern Taiwan. In 2015, the "Seismic Hazard Potential Map of the Taiwan Area" was released by the Ministry of Science and 
Technology (MOST), Taiwan. According to the MOST, the probability of a strong earthquake of magnitude 6.5 occurring in southern Taiwan within the next thirty years is $64 \%$, and the probability of a strong earthquake of magnitude 7.0 occurring in Eastern Taiwan is $20 \%$. In Taiwan, the threat of earthquakes is not negligible.

The present structural design concept is based on economic considerations. The premise is not life-threatening as long as the structural design meets the principle of suffering no damage in a small earthquake, being repairable after a moderate earthquake, and not collapsing in a large earthquake. Some damage to buildings is inevitable. However, damaged buildings need to be reinforced as quickly as possible, for aftershocks can cause further damage or total collapse before the designated life span of the buildings. To mend this kind of building, many researchers have developed active [1-4] or semiactive [5-10] bracings. For example, Chung et al. [1] carried out an experimental study on a building structure with active control subjected to base motion. Soong et al. $[2,3]$ designed and installed an active bracing system for a full-scale test structure under actual ground excitation to observe its seismic resistance. Dyke et al. [4] developed an acceleration feedback control method of active control for buildings. Symans and Constantinou [5] installed semiactive dampers in the lateral bracing of multiple degree of freedom (MDOF) test structures to test and verify the seismic control performance. Hiemenz et al. [6] presented a three-story building with semiactive magnetorheological (MR) braces under external excitation, which performed well under control efficiency. Gattulli et al. [7] proposed a prototype of a semiactive protection system for Chevron braces with embedded MR dampers. Caterino et al. [8] highlighted the several problems of structures equipped with semiactive control systems. Pourzeynali and Jooei [9] proposed a particular type of semiactive control device, the Variable Stiffness Device (VSD), and applied a Semiactive Fuzzy Logic Controller (SFLC) to this system to optimize the seismic reduction of the building responses under earthquake excitations. Hiramoto et al. [10] proposed a structural model for a semiactive control design and a model-based semiactive control law to improve the performance of the semiactive control system.

In addition, Iwan [11, 12] proposed Active Interaction Control (AIC), a semiactive control method, in 1996. The experimental and numerical analysis results [13-15] showed that the key to this AIC for dissipating the energy of external forces was the interface elements (IE), which reversed internal forces from the subordinate structures. Shih and Sung [16] installed an accumulator into a Displacement Semiactive Hydraulic Damper (DSHD) by converting it to AIC (Active Interaction Control) device. Tests indicated that the deformation of the main structure could be minimized by mutual interaction between the subordinate structure and the main structure. In this study, the Accumulated Semiactive Hydraulic Damper (ASHD) proposed by Shih and Sung $[17,18]$ was converted to Active Interaction Control (AIC). Nevertheless, "time delay" phenomena occur in research achievements [16]. In order to improve this kind of problem, the predictive control method proposed by Shih and Sung
$[19,20]$ was applied to improve the seismic proofing capability of the proposed AIC. In this study, a theoretical analysis model is derived for ASHD and converted to AIC based on the concept of AIC. The predictive control method for AIC is briefly discussed in the Methodology. Then, a fullscale two-story single-bay steel frame with ASHD converted to AIC is tested on a shaking table under the excitation of the El Centro (1940) and Kobe earthquake records to test and verify the seismic proofing capability of this proposed device under various control conditions. In this paper, the shock absorption effects of the test structure under excitation by external forces, influence of predictive time, stiffness of the auxiliary structure, and synchronous switching and asynchronous switching on the control effect of the proposed AIC, and the influence of the control positions of the test structure on the control effects of the proposed AIC are discussed to determine the optimal control conditions for the proposed AIC.

\section{Methodology}

2.1. Composition of Accumulated Semiactive Hydraulic Damper. The Accumulated Semiactive Hydraulic Damper (ASHD) is converted to an Active Interaction Control device in this study. An ASHD is a kind of controllable energy-dissipating element of a passive control system, and it is also treated as a semiactive control device. The main design concept is based on the energy-dissipating component; the damping force can be generated by the flow of fluid through the orifice so as to conduct control. An ASHD is composed of a hydraulic jack, a directional valve, a check valve, a relief valve, and an accumulator, as shown in Figure 1. The energy-dissipating characteristics of the ASHD are controlled by the flow of oil in the hydraulic jack. In this study, this ASHD is proposed as the major component of the Hydraulic Interaction Element, IE.

2.2. Theoretical Derivation of the ASHD as AIC. Assuming that two auxiliary structures (AS) are installed in the two degrees of freedom of the primary structure (PS), the organizational structure of this control system with an added mechanical sensor-switching assembly device developed from an Accumulated Semiactive Hydraulic Damper (ASHD) is shown in Figure 2. In that figure, $m_{1}, c_{1}, k_{1}, m_{2}, c_{2}$, $k_{2} ; m_{a 1}, c_{a 1}, k_{a 1}$; and $m_{a 2}, c_{a 2}, k_{a 2}$ represent the mass, damping coefficient, and stiffness of the primary structure at the 1st and 2 nd floors and of the auxiliary structures at the 1st and 2nd floors, respectively. $x_{1}$ and $x_{2}$ represent the structural displacement of the 1st and 2nd floors, with the ground as the reference frame. $x_{a 1}$ and $x_{a 2}$ represent substructural displacement of the 1st and 2nd floors, with the ground as the reference frame. $\ddot{x}_{g}$ is the acceleration of ground motion. $f_{\text {IE1 }}$ and $f_{\mathrm{IE} 2}$ denote the internal forces of the interface elements of the 1st and 2nd substructures, respectively. In this study, it is assumed that tension is positive. Therefore, the dynamic equilibrium equation of motion for these four mass blocks under excitation of earthquake forces and the internal force 


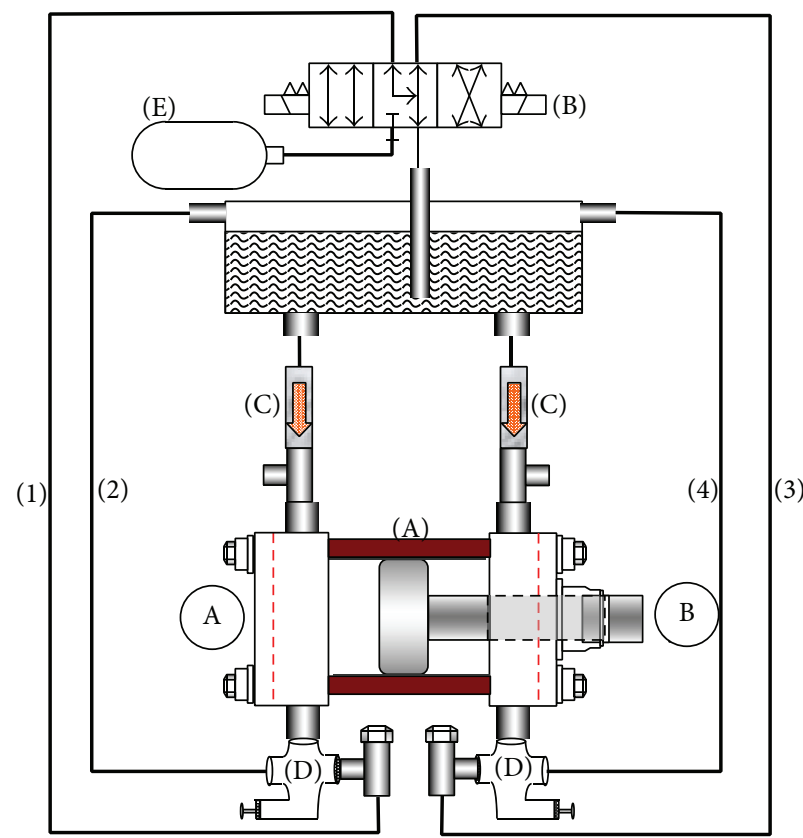
(1) Left primary hydraulic circuit
(A) Hydraulic jack
(2) Left secondary hydraulic circuit
(B) Directional valve
(4) Right secondary hydraulic circuit
(C) Check valve
(A) Connect to structure
(D) Relief valve
B Connect to bracing
(E) Accumulator

Figure 1: Framework of Accumulated Semiactive Hydraulic Device [17].

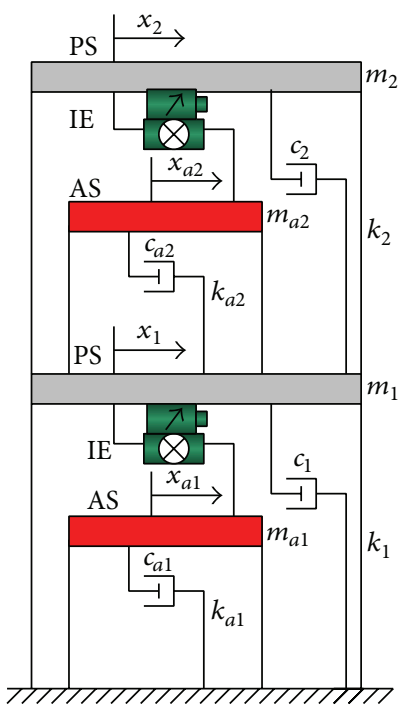

$\otimes$ Direction oriented connector with or without fuse

Mechanical sensor-switch assembly device

FIgURE 2: The systematic organization of ASHD as AIC [16]. of the interface elements of the 1st and 2nd substructures are listed as follows:

$$
\begin{aligned}
{\left[\begin{array}{cccc}
m_{1} & 0 & 0 & 0 \\
0 & m_{2} & 0 & 0 \\
0 & 0 & m_{a 1} & 0 \\
0 & 0 & 0 & m_{a 2}
\end{array}\right]\left\{\begin{array}{c}
\ddot{x}_{1} \\
\ddot{x}_{2} \\
\ddot{x}_{a 1} \\
\ddot{x}_{a 2}
\end{array}\right\} } \\
+\left[\begin{array}{cccc}
c_{1}+c_{2}+c_{a 2} & -c_{2} & 0 & -c_{a 2} \\
-c_{2} & c_{2} & 0 & 0 \\
0 & 0 & c_{a 1} & 0 \\
-c_{a 2} & 0 & 0 & c_{a 2}
\end{array}\right]\left\{\begin{array}{c}
\dot{x}_{1} \\
\dot{x}_{2} \\
\dot{x}_{a 1} \\
\dot{x}_{a 2}
\end{array}\right\} \\
+\left[\begin{array}{cccc}
k_{1}+k_{2}+k_{a 2} & -k_{2} & 0 & -k_{a 2} \\
-k_{2} & k_{2} & 0 & 0 \\
0 & 0 & k_{a 1} & 0 \\
-k_{a 2} & 0 & k_{a 2}
\end{array}\right]\left\{\begin{array}{c}
x_{1} \\
x_{2} \\
x_{a 1} \\
x_{a 2}
\end{array}\right\} \\
=-\left[\begin{array}{c}
m_{1} \\
m_{2} \\
m_{a 1} \\
m_{a 2}
\end{array}\right] \ddot{x}_{g}+\left[\begin{array}{c}
f_{\mathrm{IE} 1} \\
f_{\mathrm{IE} 2} \\
-f_{\mathrm{IE} 1} \\
-f_{\mathrm{IE} 2}
\end{array}\right] .
\end{aligned}
$$


The first item on the right-hand side of (1) is uncontrollable external force or external ground acceleration; the only controllable item is the second part-the controllable vector on the right-hand side of the equation. This controllable vector converts part of the controllability of the interaction interface element via switching IE. Each status of the control force vector of the interaction interface element is discussed as follows:

(1) Unlocked status of interaction IE: the control force of IE is zero. Auxiliary structures may freely vibrate. In this study, the auxiliary structure is considered as an independent oscillator. The equation of motion of each auxiliary structure can be expressed as follows:

$$
\begin{aligned}
& m_{a, i} \ddot{x}_{a, i}(t)+c_{a, i} \dot{x}_{a, i}(t)+k_{a, i} x_{a, i}(t) \\
& =-m_{a, i} \ddot{x}_{g}(t)+c_{a, i} \dot{x}_{i-1}(t)+k_{a, i} x_{i-1}(t)-u_{i}(t),
\end{aligned}
$$

where suffix $a, i$ represents systematic parameter of the $i$ th floor of the auxiliary structure and $u_{i}(t)$ is the $i$ th element force of the interaction IE.

(2) Locked status of interaction IE: there is an interaction acting force. The relative displacement of mass between the primary and auxiliary structures is incapable of change. Therefore, the relative displacement before the unlocked status is equal to that of just the locked status. That is,

$x_{i}(t)-x_{a, i}(t)=x_{i}\left(t_{0}\right)-x_{a, i}\left(t_{0}\right), \quad t_{0} \leq t \leq t_{1}$,

where $t_{0}$ and $t_{1}$ represent the time points at the beginnings of the locked and unlocked statuses, respectively. Suffix $i$ means the $i$ th element of IE. Equation (3) is only suitable for the time between $t_{0}$ and $t_{1}$. Therefore, the constraint condition is inferred to represent the relations of the displacement response of the auxiliary structures and primary structures, as follows:

$$
x_{a, i}(t)=x_{i}(t)-x_{i}\left(t_{0}\right)+x_{a, i}\left(t_{0}\right) .
$$

Thus, the interaction force of the $i$ th IE is as follows:

$$
\begin{aligned}
f_{\mathrm{EI}, i}= & -m_{a i}\left(\ddot{x}_{i}-\ddot{x}_{i-1}\right)-c_{a i}\left(\dot{x}_{i}-\dot{x}_{i-1}\right) \\
& -k_{a i}\left(x_{i}-x_{i-1}-x_{i, t_{0}}+x_{a i, t_{0}}\right) .
\end{aligned}
$$

2.3. Predictive Control for AIC. According to previous research [16] on applying the Semiactive Hydraulic Damper as an Active Interaction Control device, the hysteretic loops of a single floor test structure under excitation by external earthquake records show a "time delay" phenomenon. In order to improve the seismic proofing capability of this proposed ASHD as AIC, a predictive control method for a Semiactive Hydraulic Damper is applied to reduce the time delay $[19,20]$. This predictive method was proposed by Shih and Sung $[19,20]$ to diminish the time delay and improve the seismic proofing capability of an ASHD. The structural
TABLE 1: Natural frequency, damping ratio, and mass of test structure.

\begin{tabular}{lcc}
\hline Original/FL & Stiffness $(\mathrm{N} / \mathrm{m})$ & Mass $(\mathrm{kg})$ \\
\hline 1st FL & 327680 & 4402 \\
2nd FL & 327680 & 4329 \\
\hline \multirow{3}{*}{ Parameters } & Dynamic parameters & \\
\hline Frequency & Mode 1 & Mode 2 \\
Damping ratio & $0.85 \mathrm{~Hz}$ & $2.256 \mathrm{~Hz}$ \\
Mode vector & 0.0028 & 0.0033 \\
& 0.608 & -1.241 \\
\end{tabular}

responses of a test building under external excitation, namely, displacement, velocity, and acceleration, in a previous step are used to establish the signals for the next step. To ensure that the ASHD of AIC is activated on time, the request signal can be started before the optimal reverse point in order to compensate for the time delay.

The equation of the optimal displacement is shown as follows:

$$
\widehat{x}_{i}=\left\{F_{i}\right\} \cdot\{x\},
$$

where $\left\{F_{i}\right\}$ is the coefficient regression system and $\{x\}$ is the structural displacement.

The velocity can be obtained by differentiating the displacement equation with respect to time as

$$
\dot{\hat{x}}_{i}=\frac{d}{d t} \widehat{x}(t), \quad t=i \cdot \Delta t
$$

Details of the derivation of this predictive control method are provided in Appendix A.

\section{Experimental Setup}

Multiple degrees of freedom (MDOF) shaking table test is used to investigate the control performance of the proposed AIC with different control conditions: passive control, synchronous control with prediction time control, synchronous control, asynchronous control with prediction time control, and predictive control at different floors. The auxiliary structure (AS) with various stiffeners added at different floors is also tested. In this study, the El Centro (1940) and Kobe earthquake records are used as excitation inputs to the shaking table. All of the tests are full-scale shaking table tests, and all are used to test and verify the seismic proofing capability of the proposed AIC with various control conditions. The dimensions of the shaking table are $3.0 \mathrm{~m}$ $\times 3.0 \mathrm{~m}$. The maximum acceleration of the shaking table is $\pm 9.8 \mathrm{~m} / \mathrm{s}^{2}( \pm 1.0 \mathrm{~g})$ with hydraulic actuator loads of up to 15 tons. A two-story single-bay steel frame is used as the test structure, as shown in Figure 3. In order to acquire the obvious elastic deformation, all four columns of this test structure are made of $100 \mathrm{~mm} \times 32 \mathrm{~mm}$ solid steel. The mechanical characteristics of the test structure are listed in Table 1. 


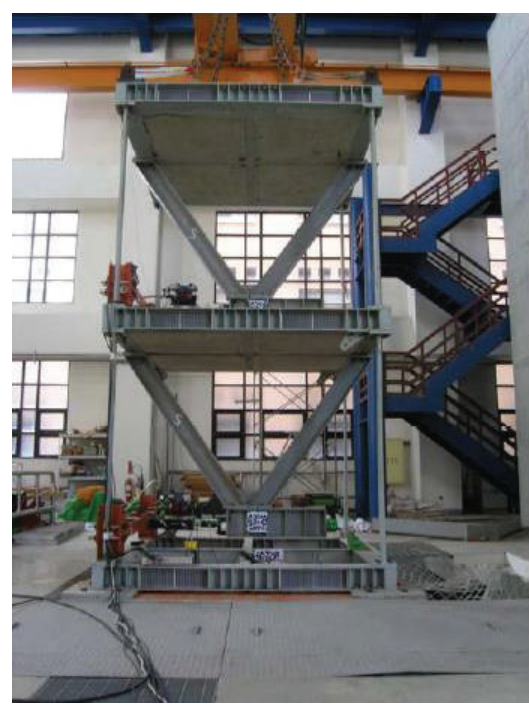

FIgure 3: The shaking table test for ASHD as AIC with various control conditions.

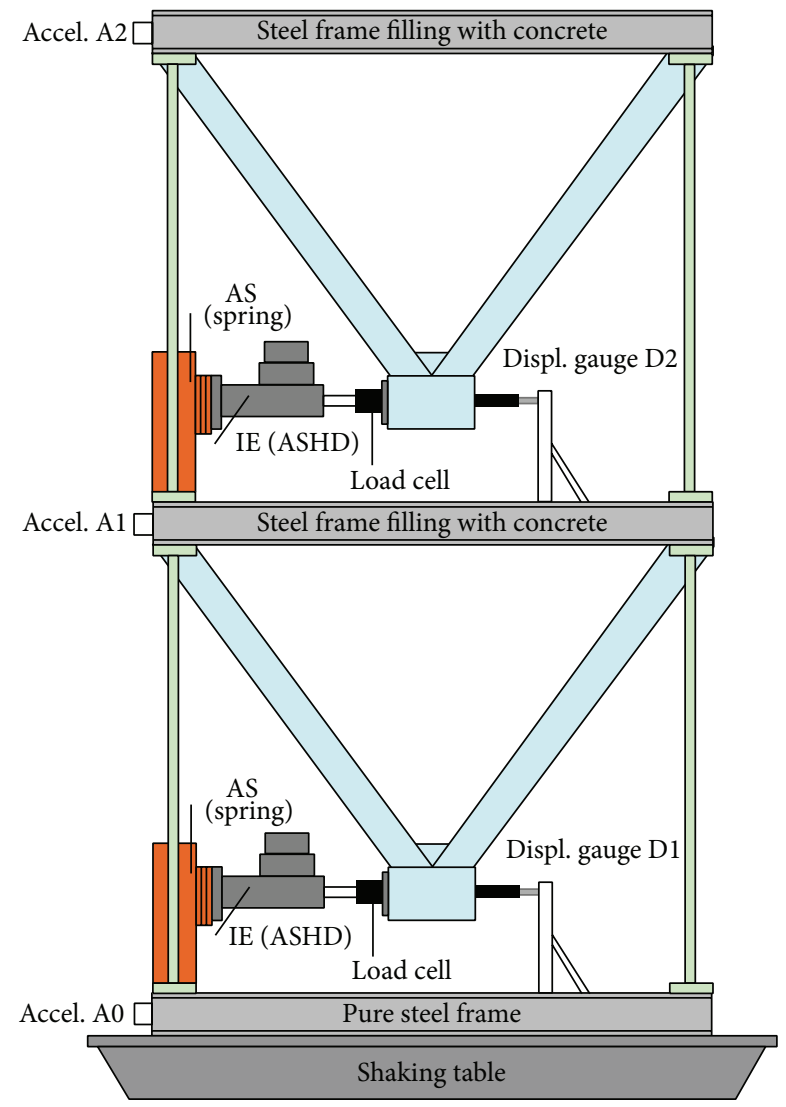

FIGURE 4: The full-scale shaking test structure added with IE, stiffeners, and sensors.

Three accelerometers, two displacement gauges, and two load cells are installed in the test model to measure the absolute acceleration, story drift, and output force of the damper. Figure 4 shows the added accelerometers, displacement gauge, and load cell on the auxiliary structures. All structural responses of this test structure are recorded with

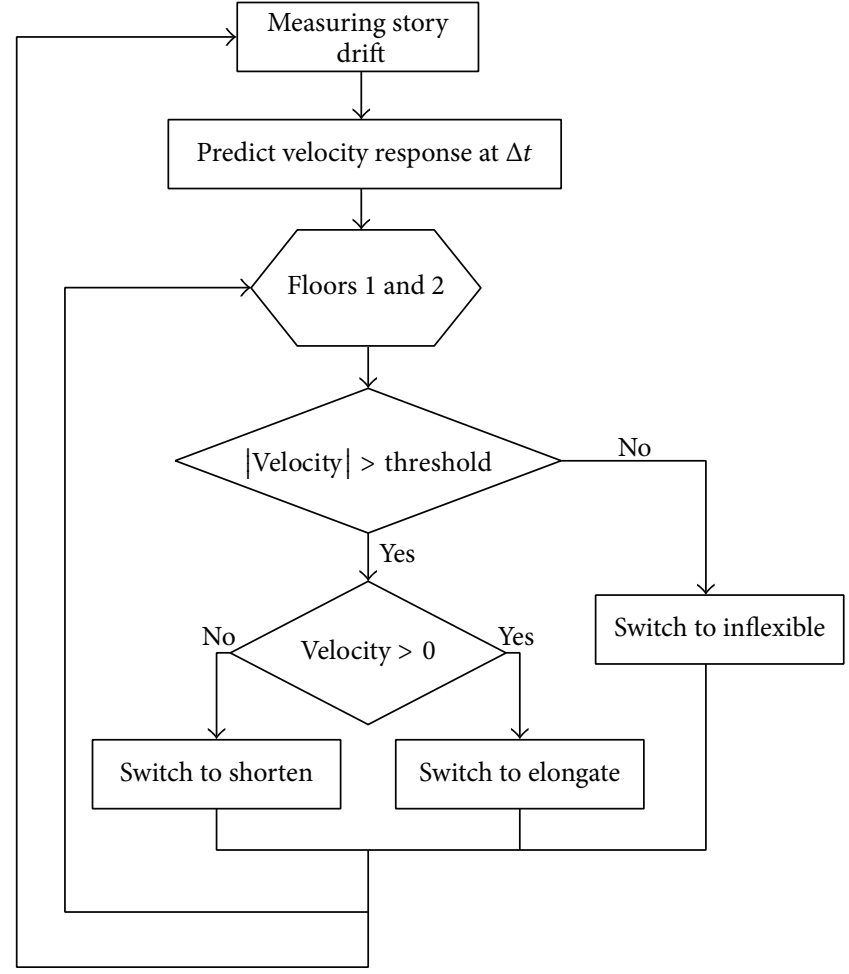

FIGURE 5: The signal process flowchart of this full-scale shaking table test.

the signal processing flowchart of the control computer, as shown in Figure 5.

\section{Test Results and Discussion}

4.1. The Maximum Shock Absorption Effects of Structure with Various Control Conditions under Excitation of the El Centro and Kobe Earthquake Record. To compare the seismic proofing capability of the proposed AIC under various control conditions, a two-story single-bay steel frame without control is excited with various earthquake records to obtain the time history of the structural responses of story drift, absolute acceleration, and base shear and thereby to determine the maximum structural responses. This test structure is tested under multiple control conditions: (1) passive control (i) with 2 stiffeners added at the 1st and 2nd floors and (ii) with 4 stiffeners added at the 1st floor and 3 stiffeners at the 2nd floor and (2) Active Interaction Control with (i) 2 stiffeners at the 1st and 2nd floors combined with synchronous control and predictive control of $0.13,0.10$, and 0.07 seconds, (ii) synchronous control with no predictive control, and (iii) asynchronous control with predictive control of 0.10 seconds. Then, testing conditions for location of control are 2 stiffeners added at the 1st and 2nd floors and (i) control at the 1st floor with predictive control of 0.10 seconds and (ii) control at the 2nd floor with predictive control of 0.10 seconds. Finally, a test structure with 4 stiffeners at the 1st floor and 3 stiffeners at the 2nd floor is tested with synchronous predictive control of 0.10 seconds. All test structures with 

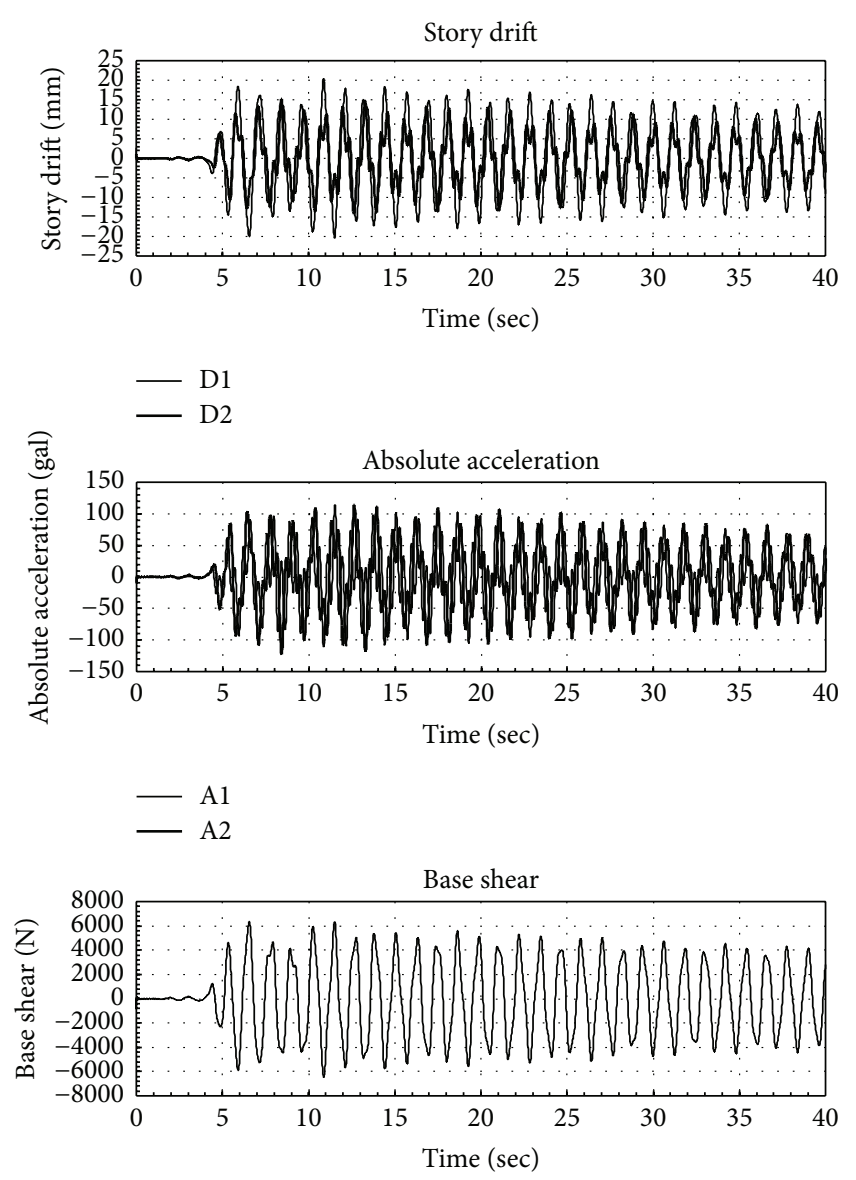

FIgURE 6: Time history of story drift, absolute acceleration, and base shear responses of bare structure under excitation of Kobe earthquake record with $\mathrm{PGA}=0.50 \mathrm{~m} / \mathrm{sec}^{2}$ (50 gal).

various control conditions and added various stiffeners are under excitation with the El Centro and Kobe earthquake records, with various peak ground acceleration rates. All test results are analyzed to determine the maximum responses and ratios of the maximum shock absorption; those results are listed in Tables $2-5$. The typical time history of story drift, absolute acceleration, and base shear response of the bare test structure under excitation of the Kobe earthquake are shown in Figure 6. The typical time history of story drift, absolute acceleration, and base shear response of the test structure with two stiffeners and synchronous predictive control of 0.13 seconds under excitation of the Kobe earthquake are shown in Figure 7. The maximum response of base shear; acceleration records at the base, 1st floor, and 2nd floor; and displacement records at the 1st and 2nd floors of the test structure under excitation of the El Centro and Kobe earthquake records with various peak ground acceleration rates are listed in Tables 2 and 3, respectively, located in Appendix B. Ratios of the maximum shock absorption of the test structure under excitation of the El Centro and Kobe earthquake records with various peak ground acceleration rates are listed in Tables 4 and 5, respectively.
All of the control methods provide shock absorption of displacement. However, the displacement shock absorption of the test structure is less under excitation of the Kobe earthquake record than under excitation of the El Centro earthquake record. Although the structural response of displacement can be reduced by a passive stiffened structure, the decrement rate is not proportional to the stiffness ratio. Notably, adding more stiffeners increases the structural responses to acceleration and base shear. Actually, dynamic responses are relative to structural frequencies. The test and analysis results of Tables 4 and 5 are discussed as follows.

(1) Synchronous Control with and without Predictive Control. The results in Tables 4 and 5 show that the structural responses to displacement, acceleration, and base shear of the test structure are effectively reduced by the proposed AIC with synchronous control with and without predictive control under excitation of the El Centro and Kobe earthquake records with various peak ground acceleration rates. For the proposed AIC with synchronous control and predictive control of $0.10 \sim 0.13$ seconds, the shock absorption ratios of displacement are greater than $71 \%$, the average acceleration reduction ratios are $36.2 \%$ and $36.9 \%$ at the 1 st and 2 nd floors, respectively, and the average base shear reduction ratio is $29.6 \%$ for the test structure. For the proposed AIC with synchronous control and predictive control of 0.07 seconds, the shock absorption reduction ratios of displacement are greater than $55 \%$, the average acceleration control reduction ratios are $19 \%$ and $7.7 \%$ at the 1 st and 2 nd floors, respectively, and the average base shear reduction ratio is $6 \%$ for the test structure. For synchronous control without predictive control, the shock absorption ratios of displacement are greater than $54 \%$, the average acceleration reduction ratios are $31 \%$ and $14 \%$ at the 1st and 2nd floors, respectively, and the average base shear reduction ratio is $11 \%$. The test results in Table 5 reveal that, for the proposed AIC with synchronous control and predictive control of $0.10 \sim 0.13$ seconds, the shock absorption reduction ratios of displacement are greater than $54 \%$, the average acceleration reduction ratios are $34 \%$ and $3.13 \%$ at the 1st and 2nd floors, respectively, and the average base shear reduction ratio is increased slightly. For synchronous control with predictive control of 0.07 seconds, the shock absorption ratios of displacement are greater than $28 \%$ and the acceleration response of the 1st floor is reduced. However, the acceleration response increased slightly at the 2 nd floor and base shear increased by $76.1 \%$. For synchronous control without predictive control, the average shock absorption ratios of displacement are $26 \%$ and $41 \%$ at the 1st and 2 nd floors, respectively, but the average acceleration increased by $3 \%$ at the 1 st floor and $42.5 \%$ at the 2 nd floor; in addition, the base shear increased by $95.6 \%$. All of the control effects of the proposed AIC with synchronous control with and without predictive control are superior to those of passive control.

(2) Asynchronous Control with Predictive Control. The test results in Table 4 show that the shock absorption ratio of displacement of the test structure under asynchronous control with predictive control of 0.07 seconds is greater than 52\%, superior to that of the test structure under passive control. 
TABLE 2: The maximum structural response of test structure under excitation of El Centro earthquake record with various control conditions and different peak ground acceleration.

\begin{tabular}{|c|c|c|c|c|c|c|c|c|}
\hline $\begin{array}{l}\text { Number of } \\
\text { stiffeners at } \\
\text { 1st floor }\end{array}$ & $\begin{array}{l}\text { Number of } \\
\text { stiffeners at } \\
\text { 2nd floor }\end{array}$ & Control conditions & $\begin{array}{l}\mathrm{A} 0 \\
\mathrm{~m} / \mathrm{sec}^{2}\end{array}$ & $\begin{array}{l}\mathrm{D} 1 \\
\mathrm{~mm}\end{array}$ & $\begin{array}{l}\mathrm{D} 2 \\
\mathrm{~mm}\end{array}$ & $\begin{array}{c}\mathrm{A} 1 \\
\mathrm{~m} / \mathrm{sec}^{2}\end{array}$ & $\begin{array}{c}\mathrm{A} 2 \\
\mathrm{~m} / \mathrm{sec}^{2}\end{array}$ & $\begin{array}{l}\text { Base shear } \\
\mathrm{kN}\end{array}$ \\
\hline 0 & 0 & NC & 0.445 & 25.8 & 16.8 & 1.057 & 1.353 & 8.2 \\
\hline 2 & 2 & Passive & 0.423 & 17.5 & 9.9 & 1.393 & 1.701 & 12.4 \\
\hline 2 & 2 & Passive & 0.908 & 33.4 & 18.1 & 3.149 & 3.121 & 25.4 \\
\hline 4 & 3 & Passive & 0.439 & 14.0 & 10.7 & 1.616 & 2.408 & 15.8 \\
\hline 4 & 3 & Passive & 0.795 & 25.7 & 18.8 & 3.000 & 4.178 & 29.7 \\
\hline 2 & 2 & $\begin{array}{l}\text { Synchronic and } 0.13 \text {-second } \\
\text { predictive control }\end{array}$ & 2.159 & 29.7 & 23.0 & 2.941 & 3.967 & 24.5 \\
\hline 2 & 2 & $\begin{array}{l}\text { Synchronic and } 0.13 \text {-second } \\
\text { predictive control }\end{array}$ & 1.758 & 23.7 & 17.7 & 2.632 & 3.349 & 24.1 \\
\hline 2 & 2 & $\begin{array}{l}\text { Synchronic and } 0.13 \text {-second } \\
\text { predictive control }\end{array}$ & 1.335 & 17.6 & 12.7 & 1.791 & 2.401 & 15.3 \\
\hline 2 & 2 & $\begin{array}{l}\text { Synchronic and } 0.13 \text {-second } \\
\text { predictive control }\end{array}$ & 0.957 & 12.0 & 8.1 & 1.807 & 1.708 & 13.6 \\
\hline 2 & 2 & $\begin{array}{l}\text { Synchronic and } 0.13 \text {-second } \\
\text { predictive control }\end{array}$ & 0.474 & 7.4 & 5.3 & 1.228 & 1.045 & 8.6 \\
\hline 2 & 2 & $\begin{array}{l}\text { Synchronic and } 0.10 \text {-second } \\
\text { predictive control }\end{array}$ & 2.189 & 31.0 & 24.1 & 3.095 & 4.413 & 25.7 \\
\hline 2 & 2 & $\begin{array}{l}\text { Synchronic and } 0.10 \text {-second } \\
\text { predictive control }\end{array}$ & 2.119 & 23.5 & 17.8 & 2.180 & 3.336 & 21.3 \\
\hline 2 & 2 & $\begin{array}{l}\text { Synchronic and } 0.10 \text {-second } \\
\text { predictive control }\end{array}$ & 1.503 & 17.3 & 12.7 & 1.669 & 2.512 & 14.5 \\
\hline 2 & 2 & $\begin{array}{l}\text { Synchronic and } 0.10 \text {-second } \\
\text { predictive control }\end{array}$ & 0.870 & 11.4 & 8.1 & 1.063 & 1.801 & 9.9 \\
\hline 2 & 2 & $\begin{array}{l}\text { Synchronic and } 0.10 \text {-second } \\
\text { predictive control }\end{array}$ & 0.476 & 7.5 & 5.2 & 0.806 & 1.098 & 8.3 \\
\hline 2 & 2 & $\begin{array}{l}\text { Synchronic and } 0.07 \text {-second } \\
\text { predictive control }\end{array}$ & 1.222 & 24.4 & 19.2 & 2.249 & 3.485 & 20.5 \\
\hline 2 & 2 & $\begin{array}{l}\text { Synchronic and } 0.07 \text {-second } \\
\text { predictive control }\end{array}$ & 0.881 & 18.1 & 14.0 & 1.515 & 2.364 & 14.3 \\
\hline 2 & 2 & $\begin{array}{l}\text { Synchronic and } 0.07 \text {-second } \\
\text { predictive control }\end{array}$ & 0.422 & 10.1 & 7.2 & 0.927 & 1.221 & 7.9 \\
\hline 2 & 2 & Synchronic control & 1.406 & 25.9 & 20.5 & 2.301 & 3.677 & 21.0 \\
\hline 2 & 2 & Synchronic control & 0.928 & 18.5 & 14.1 & 1.505 & 2.392 & 14.2 \\
\hline 2 & 2 & Synchronic control & 0.423 & 11.0 & 7.3 & 0.903 & 1.267 & 8.1 \\
\hline 2 & 2 & $\begin{array}{l}\text { Asynchronic and } 0.10 \text {-second } \\
\text { predictive control }\end{array}$ & 1.646 & 31.4 & 26.7 & 6.112 & 4.653 & 28.7 \\
\hline 2 & 2 & $\begin{array}{l}\text { Asynchronic and } 0.10 \text {-second } \\
\text { predictive control }\end{array}$ & 1.473 & 21.4 & 19.6 & 4.199 & 3.445 & 19.1 \\
\hline 2 & 2 & $\begin{array}{l}\text { Asynchronic and } 0.10 \text {-second } \\
\text { predictive control }\end{array}$ & 0.855 & 17.8 & 14.2 & 2.749 & 2.629 & 11.5 \\
\hline 2 & 2 & $\begin{array}{c}\text { Asynchronic and } 0.10 \text {-second } \\
\text { predictive control }\end{array}$ & 0.456 & 9.0 & 8.3 & 1.663 & 1.443 & 7.0 \\
\hline 2 & 2 & $\begin{array}{l}0.10 \text {-second predictive control at } 1 \text { st } \\
\text { floor }\end{array}$ & 1.642 & 30.0 & 30.7 & 6.782 & 5.908 & 29.0 \\
\hline 2 & 2 & $\begin{array}{l}0.10 \text {-second predictive control at } 1 \text { st } \\
\text { floor }\end{array}$ & 1.259 & 22.1 & 22.8 & 4.928 & 4.238 & 20.9 \\
\hline 2 & 2 & $\begin{array}{l}0.10 \text {-second predictive control at } 1 \text { st } \\
\text { floor }\end{array}$ & 0.971 & 16.4 & 15.7 & 3.250 & 2.767 & 13.1 \\
\hline 2 & 2 & $\begin{array}{l}0.10 \text {-second predictive control at 1st } \\
\text { floor }\end{array}$ & 0.437 & 8.8 & 8.4 & 1.774 & 1.547 & 7.7 \\
\hline
\end{tabular}


TABLE 2: Continued.

\begin{tabular}{|c|c|c|c|c|c|c|c|c|}
\hline $\begin{array}{l}\text { Number of } \\
\text { stiffeners at } \\
\text { 1st floor }\end{array}$ & $\begin{array}{l}\text { Number of } \\
\text { stiffeners at } \\
\text { 2nd floor }\end{array}$ & Control conditions & $\begin{array}{c}\mathrm{A} 0 \\
\mathrm{~m} / \mathrm{sec}^{2}\end{array}$ & $\begin{array}{l}\mathrm{D} 1 \\
\mathrm{~mm}\end{array}$ & $\begin{array}{l}\mathrm{D} 2 \\
\mathrm{~mm}\end{array}$ & $\begin{array}{c}\mathrm{A} 1 \\
\mathrm{~m} / \mathrm{sec}^{2}\end{array}$ & $\begin{array}{c}\mathrm{A} 2 \\
\mathrm{~m} / \mathrm{sec}^{2}\end{array}$ & $\begin{array}{c}\text { Base shear } \\
\text { kN }\end{array}$ \\
\hline 2 & 2 & $\begin{array}{l}0.10 \text {-second predictive control at } \\
\text { 2nd floor }\end{array}$ & 0.851 & 24.2 & 20.9 & 3.727 & 3.798 & 20.9 \\
\hline 2 & 2 & $\begin{array}{l}0.10 \text {-second predictive control at } \\
\text { 2nd floor }\end{array}$ & 0.465 & 12.8 & 11.2 & 1.759 & 1.902 & 11.1 \\
\hline 4 & 3 & $\begin{array}{c}\text { Synchronic and } 0.10 \text {-second } \\
\text { predictive control }\end{array}$ & 2.607 & 26.6 & 23.3 & 4.674 & 6.536 & 37.1 \\
\hline 4 & 3 & $\begin{array}{l}\text { Synchronic and } 0.10 \text {-second } \\
\text { predictive control }\end{array}$ & 2.374 & 21.9 & 20.3 & 4.116 & 5.336 & 35.3 \\
\hline 4 & 3 & $\begin{array}{l}\text { Synchronic and } 0.10 \text {-second } \\
\text { predictive control }\end{array}$ & 1.934 & 18.5 & 17.3 & 3.619 & 4.853 & 26.1 \\
\hline 4 & 3 & $\begin{array}{l}\text { Synchronic and } 0.10 \text {-second } \\
\text { predictive control }\end{array}$ & 1.295 & 14.8 & 13.5 & 2.913 & 3.406 & 22.3 \\
\hline 4 & 3 & $\begin{array}{l}\text { Synchronic and } 0.10 \text {-second } \\
\text { predictive control }\end{array}$ & 0.914 & 10.1 & 10.0 & 1.788 & 2.378 & 14.7 \\
\hline 4 & 3 & $\begin{array}{c}\text { Synchronic and } 0.10 \text {-second } \\
\text { predictive control }\end{array}$ & 0.435 & 6.5 & 4.1 & 0.883 & 1.379 & 9.4 \\
\hline
\end{tabular}
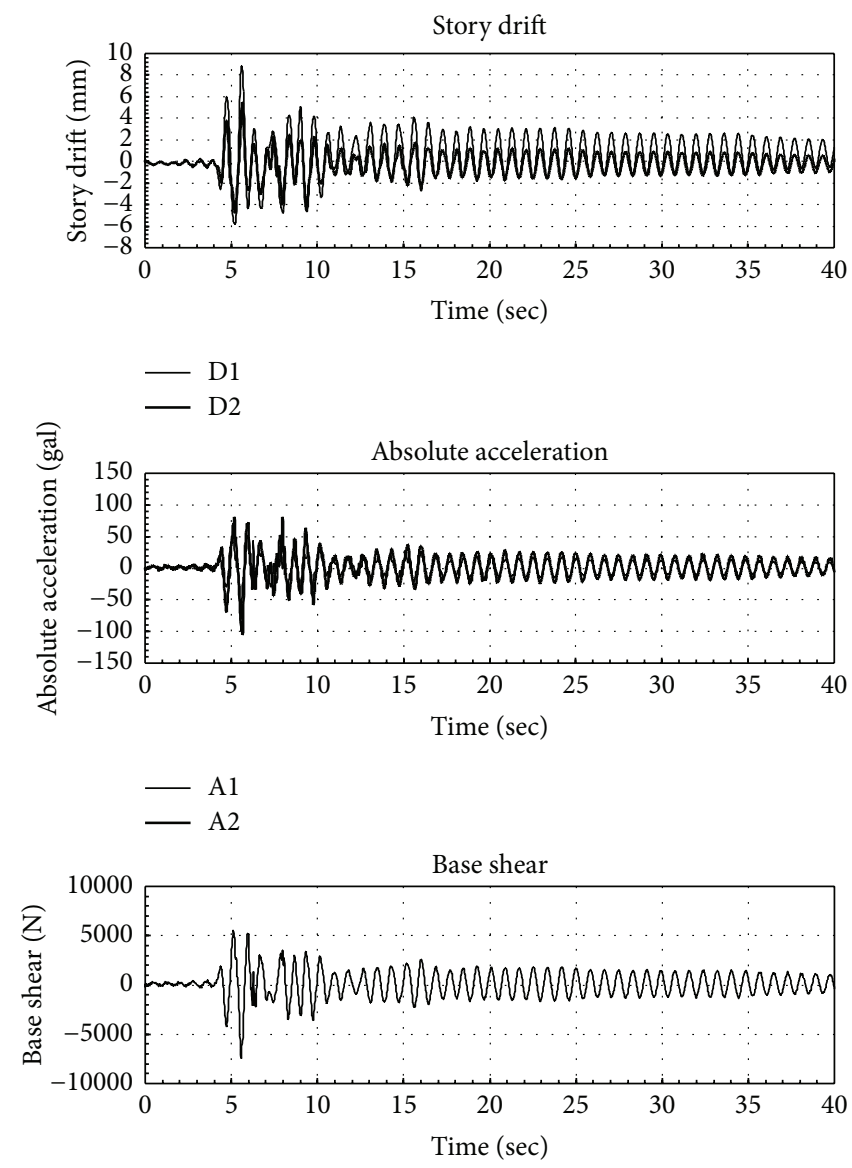

FIGURE 7: Time history of story drift, absolute acceleration, and base shear responses of test structure added with two stiffeners and with synchronic and 0.13 -second predictive control under excitation of Kobe earthquake record with PGA $=0.50 \mathrm{~m} / \mathrm{sec}^{2}(50 \mathrm{gal})$. 
TABLE 3: The maximum structural response of test structure under excitation of Kobe earthquake record with various control conditions and different peak ground acceleration.

\begin{tabular}{|c|c|c|c|c|c|c|c|c|}
\hline $\begin{array}{l}\text { Number of } \\
\text { stiffeners at } \\
\text { 1st floor }\end{array}$ & $\begin{array}{l}\text { Number of } \\
\text { stiffeners at } \\
\text { 2nd floor }\end{array}$ & Control conditions & $\begin{array}{c}\mathrm{A} 0 \\
\mathrm{~m} / \mathrm{sec}^{2}\end{array}$ & $\begin{array}{l}\mathrm{D} 1 \\
\mathrm{~mm}\end{array}$ & $\begin{array}{l}\mathrm{D} 2 \\
\mathrm{~mm}\end{array}$ & $\begin{array}{c}\mathrm{A} 1 \\
\mathrm{~m} / \mathrm{sec}^{2}\end{array}$ & $\begin{array}{c}\mathrm{A} 2 \\
\mathrm{~m} / \mathrm{sec}^{2}\end{array}$ & $\begin{array}{c}\text { Base shear } \\
\text { kN }\end{array}$ \\
\hline 0 & 0 & $\mathrm{NC}$ & 0.693 & 28.8 & 21.7 & 1.637 & 1.751 & 9.0 \\
\hline 2 & 2 & Passive & 0.940 & 33.2 & 20.5 & 3.217 & 3.549 & 26.0 \\
\hline 4 & 3 & Passive & 0.534 & 16.1 & 12.8 & 1.863 & 2.854 & 18.4 \\
\hline 4 & 3 & Passive & 0.938 & 30.0 & 22.2 & 3.618 & 4.982 & 34.9 \\
\hline 2 & 2 & $\begin{array}{l}\text { Synchronic and } 0.13 \text {-second } \\
\text { predictive control }\end{array}$ & 2.053 & 32.0 & 25.4 & 3.292 & 4.657 & 29.5 \\
\hline 2 & 2 & $\begin{array}{l}\text { Synchronic and } 0.13 \text {-second } \\
\text { predictive control }\end{array}$ & 1.396 & 24.8 & 18.5 & 2.056 & 3.546 & 22.4 \\
\hline 2 & 2 & $\begin{array}{l}\text { Synchronic and } 0.13 \text {-second } \\
\text { predictive control }\end{array}$ & 1.082 & 16.9 & 11.6 & 1.380 & 2.247 & 15.6 \\
\hline 2 & 2 & $\begin{array}{l}\text { Synchronic and } 0.13 \text {-second } \\
\text { predictive control }\end{array}$ & 0.458 & 8.9 & 5.5 & 0.809 & 1.051 & 7.5 \\
\hline 2 & 2 & $\begin{array}{l}\text { Synchronic and } 0.10 \text {-second } \\
\text { predictive control }\end{array}$ & 1.973 & 32.2 & 25.4 & 3.310 & 5.298 & 31.7 \\
\hline 2 & 2 & $\begin{array}{l}\text { Synchronic and } 0.10 \text {-second } \\
\text { predictive control }\end{array}$ & 1.378 & 23.9 & 17.8 & 2.233 & 3.548 & 23.3 \\
\hline 2 & 2 & $\begin{array}{l}\text { Synchronic and } 0.10 \text {-second } \\
\text { predictive control }\end{array}$ & 0.946 & 16.3 & 11.0 & 1.362 & 2.441 & 14.5 \\
\hline 2 & 2 & $\begin{array}{l}\text { Synchronic and } 0.10 \text {-second } \\
\text { predictive control }\end{array}$ & 0.503 & 8.7 & 5.5 & 0.817 & 1.282 & 7.9 \\
\hline 2 & 2 & $\begin{array}{l}\text { Synchronic and } 0.07 \text {-second } \\
\text { predictive control }\end{array}$ & 0.919 & 26.1 & 15.9 & 2.160 & 3.081 & 21.8 \\
\hline 2 & 2 & $\begin{array}{l}\text { Synchronic and } 0.07 \text {-second } \\
\text { predictive control }\end{array}$ & 0.485 & 14.6 & 9.1 & 1.032 & 1.560 & 11.1 \\
\hline 2 & 2 & Synchronic control & 0.862 & 26.6 & 15.9 & 2.164 & 3.041 & 21.6 \\
\hline 2 & 2 & Synchronic control & 0.436 & 14.7 & 9.1 & 1.026 & 1.598 & 11.3 \\
\hline 2 & 2 & $\begin{array}{l}\text { Asynchronic and } 0.10 \text {-second } \\
\text { predictive control }\end{array}$ & 1.099 & 26.5 & 15.7 & 3.141 & 3.173 & 19.7 \\
\hline 2 & 2 & $\begin{array}{l}\text { Asynchronic and } 0.10 \text {-second } \\
\text { predictive control }\end{array}$ & 0.477 & 9.0 & 8.6 & 1.505 & 1.428 & 8.2 \\
\hline 2 & 2 & $\begin{array}{l}0.10 \text {-second predictive control at 1st } \\
\text { floor }\end{array}$ & 1.337 & 29.9 & 26.9 & 4.914 & 4.652 & 25.6 \\
\hline 2 & 2 & $\begin{array}{l}0.10 \text {-second predictive control at 1st } \\
\text { floor }\end{array}$ & 1.160 & 18.4 & 17.8 & 3.067 & 3.254 & 16.6 \\
\hline 2 & 2 & $\begin{array}{l}0.10 \text {-second predictive control at 1st } \\
\text { floor }\end{array}$ & 0.482 & 8.8 & 8.3 & 1.561 & 1.509 & 8.0 \\
\hline 2 & 2 & $\begin{array}{l}0.10 \text {-second predictive control at } \\
\text { 2nd floor }\end{array}$ & 0.917 & 29.1 & 20.8 & 4.347 & 3.920 & 26.3 \\
\hline 2 & 2 & $\begin{array}{l}0.10 \text {-second predictive control at } \\
\text { 2nd floor }\end{array}$ & 0.489 & 15.0 & 11.0 & 2.051 & 2.155 & 12.2 \\
\hline 4 & 3 & $\begin{array}{c}\text { Synchronic and } 0.10 \text {-second } \\
\text { predictive control }\end{array}$ & 2.375 & 26.3 & 19.3 & 3.167 & 4.549 & 31.6 \\
\hline 4 & 3 & $\begin{array}{l}\text { Synchronic and } 0.10 \text {-second } \\
\text { predictive control }\end{array}$ & 1.752 & 20.8 & 15.5 & 2.443 & 3.691 & 26.2 \\
\hline 4 & 3 & $\begin{array}{l}\text { Synchronic and } 0.10 \text {-second } \\
\text { predictive control }\end{array}$ & 1.355 & 15.3 & 12.3 & 1.771 & 2.851 & 19.9 \\
\hline 4 & 3 & $\begin{array}{l}\text { Synchronic and } 0.10 \text {-second } \\
\text { predictive control }\end{array}$ & 0.925 & 9.1 & 8.0 & 1.236 & 1.823 & 12.2 \\
\hline 4 & 3 & $\begin{array}{l}\text { Synchronic and } 0.10 \text {-second } \\
\text { predictive control }\end{array}$ & 0.515 & 5.6 & 4.4 & 0.710 & 1.577 & 5.8 \\
\hline
\end{tabular}


TABLE 4: The ratios of maximum shock absorption of test structure under excitation of El Centro earthquake record with various control conditions and different peak ground acceleration.

\begin{tabular}{|c|c|c|c|c|c|c|c|c|}
\hline $\begin{array}{l}\text { Number of } \\
\text { stiffeners at } \\
\text { 1st floor }\end{array}$ & $\begin{array}{l}\text { Number of } \\
\text { stiffeners at } \\
\text { 2nd floor }\end{array}$ & Control conditions & A0 & D1 & $\mathrm{D} 2$ & $\mathrm{~A} 1$ & A2 & Base shear \\
\hline 0 & 0 & $\mathrm{NC}$ & 44.5 & $0 \%$ & $0 \%$ & $0 \%$ & $0 \%$ & $0 \%$ \\
\hline 2 & 2 & Passive & 42.3 & $29 \%$ & $38 \%$ & $-39 \%$ & $-32 \%$ & $-60 \%$ \\
\hline 2 & 2 & Passive & 90.8 & $36 \%$ & $47 \%$ & $-46 \%$ & $-13 \%$ & $-52 \%$ \\
\hline 4 & 3 & Passive & 43.9 & $45 \%$ & $35 \%$ & $-55 \%$ & $-81 \%$ & $-97 \%$ \\
\hline 4 & 3 & Passive & 79.5 & $44 \%$ & $37 \%$ & $-59 \%$ & $-73 \%$ & $-104 \%$ \\
\hline 2 & 2 & $\begin{array}{l}\text { Synchronic and } 0.13 \text {-second } \\
\text { predictive control }\end{array}$ & 215.9 & $76 \%$ & $72 \%$ & $43 \%$ & $40 \%$ & $38 \%$ \\
\hline 2 & 2 & $\begin{array}{l}\text { Synchronic and } 0.13 \text {-second } \\
\text { predictive control }\end{array}$ & 175.8 & $77 \%$ & $73 \%$ & $37 \%$ & $37 \%$ & $25 \%$ \\
\hline 2 & 2 & $\begin{array}{l}\text { Synchronic and } 0.13 \text {-second } \\
\text { predictive control }\end{array}$ & 133.5 & $77 \%$ & $75 \%$ & $43 \%$ & $41 \%$ & $38 \%$ \\
\hline 2 & 2 & $\begin{array}{l}\text { Synchronic and } 0.13 \text {-second } \\
\text { predictive control }\end{array}$ & 95.7 & $78 \%$ & $78 \%$ & $20 \%$ & $41 \%$ & $23 \%$ \\
\hline 2 & 2 & $\begin{array}{l}\text { Synchronic and } 0.13 \text {-second } \\
\text { predictive control }\end{array}$ & 47.4 & $73 \%$ & $71 \%$ & $-9 \%$ & $27 \%$ & $1 \%$ \\
\hline 2 & 2 & $\begin{array}{l}\text { Synchronic and } 0.10 \text {-second } \\
\text { predictive control }\end{array}$ & 218.9 & $76 \%$ & $71 \%$ & $40 \%$ & $34 \%$ & $36 \%$ \\
\hline 2 & 2 & $\begin{array}{l}\text { Synchronic and } 0.10 \text {-second } \\
\text { predictive control }\end{array}$ & 211.9 & $81 \%$ & $78 \%$ & $57 \%$ & $48 \%$ & $45 \%$ \\
\hline 2 & 2 & $\begin{array}{l}\text { Synchronic and } 0.10 \text {-second } \\
\text { predictive control }\end{array}$ & 150.3 & $80 \%$ & $78 \%$ & $53 \%$ & $45 \%$ & $47 \%$ \\
\hline 2 & 2 & $\begin{array}{l}\text { Synchronic and } 0.10 \text {-second } \\
\text { predictive control }\end{array}$ & 87.0 & $77 \%$ & $75 \%$ & $49 \%$ & $32 \%$ & $38 \%$ \\
\hline 2 & 2 & $\begin{array}{l}\text { Synchronic and } 0.10 \text {-second } \\
\text { predictive control }\end{array}$ & 47.6 & $73 \%$ & $71 \%$ & $29 \%$ & $24 \%$ & $5 \%$ \\
\hline 2 & 2 & $\begin{array}{l}\text { Synchronic and } 0.07 \text {-second } \\
\text { predictive control }\end{array}$ & 122.2 & $65 \%$ & $58 \%$ & $22 \%$ & $6 \%$ & $9 \%$ \\
\hline 2 & 2 & $\begin{array}{l}\text { Synchronic and } 0.07 \text {-second } \\
\text { predictive control }\end{array}$ & 88.1 & $64 \%$ & $58 \%$ & $28 \%$ & $12 \%$ & $12 \%$ \\
\hline 2 & 2 & $\begin{array}{l}\text { Synchronic and } 0.07 \text {-second } \\
\text { predictive control }\end{array}$ & 42.2 & $59 \%$ & $55 \%$ & $7 \%$ & $5 \%$ & $-3 \%$ \\
\hline 2 & 2 & Synchronic control & 140.6 & $68 \%$ & $61 \%$ & $31 \%$ & $14 \%$ & $18 \%$ \\
\hline 2 & 2 & Synchronic control & 92.8 & $66 \%$ & $60 \%$ & $32 \%$ & $15 \%$ & $17 \%$ \\
\hline 2 & 2 & Synchronic control & 42.3 & $55 \%$ & $54 \%$ & $10 \%$ & $1 \%$ & $-4 \%$ \\
\hline 2 & 2 & $\begin{array}{l}\text { Asynchronic and } 0.10 \text {-second } \\
\text { predictive control }\end{array}$ & 164.6 & $67 \%$ & $57 \%$ & $-56 \%$ & $7 \%$ & $5 \%$ \\
\hline 2 & 2 & $\begin{array}{l}\text { Asynchronic and } 0.10 \text {-second } \\
\text { predictive control }\end{array}$ & 147.3 & $75 \%$ & $65 \%$ & $-20 \%$ & $23 \%$ & $29 \%$ \\
\hline 2 & 2 & $\begin{array}{l}\text { Asynchronic and } 0.10 \text {-second } \\
\text { predictive control }\end{array}$ & 85.5 & $64 \%$ & $56 \%$ & $-35 \%$ & $-1 \%$ & $26 \%$ \\
\hline 2 & 2 & $\begin{array}{c}\text { Asynchronic and } 0.10 \text {-second } \\
\text { predictive control }\end{array}$ & 45.6 & $66 \%$ & $52 \%$ & $-54 \%$ & $-4 \%$ & $16 \%$ \\
\hline 2 & 2 & $\begin{array}{l}0.10 \text {-second predictive control at 1st } \\
\text { floor }\end{array}$ & 164.2 & $68 \%$ & $50 \%$ & $-74 \%$ & $-18 \%$ & $3 \%$ \\
\hline 2 & 2 & $\begin{array}{l}0.10 \text {-second predictive control at 1st } \\
\text { floor }\end{array}$ & 125.9 & $70 \%$ & $52 \%$ & $-65 \%$ & $-11 \%$ & $9 \%$ \\
\hline 2 & 2 & $\begin{array}{c}0.10 \text {-second predictive control at 1st } \\
\text { floor }\end{array}$ & 97.1 & $71 \%$ & $57 \%$ & $-41 \%$ & $6 \%$ & $26 \%$ \\
\hline
\end{tabular}


TABLE 4: Continued.

\begin{tabular}{|c|c|c|c|c|c|c|c|c|}
\hline $\begin{array}{l}\text { Number of } \\
\text { stiffeners at } \\
\text { 1st floor }\end{array}$ & $\begin{array}{l}\text { Number of } \\
\text { stiffeners at } \\
\text { 2nd floor }\end{array}$ & Control conditions & A0 & D1 & $\mathrm{D} 2$ & $\mathrm{~A} 1$ & A2 & Base shear \\
\hline 2 & 2 & $\begin{array}{l}0.10 \text {-second predictive control at 1st } \\
\text { floor }\end{array}$ & 43.7 & $65 \%$ & $49 \%$ & $-71 \%$ & $-16 \%$ & $4 \%$ \\
\hline 2 & 2 & $\begin{array}{l}0.10 \text {-second predictive control at } \\
\text { 2nd floor }\end{array}$ & 85.1 & $51 \%$ & $35 \%$ & $-84 \%$ & $-47 \%$ & $-34 \%$ \\
\hline 2 & 2 & $\begin{array}{l}0.10 \text {-second predictive control at } \\
\text { 2nd floor }\end{array}$ & 46.5 & $53 \%$ & $36 \%$ & $-59 \%$ & $-35 \%$ & $-31 \%$ \\
\hline 4 & 3 & $\begin{array}{c}\text { Synchronic and } 0.10 \text {-second } \\
\text { predictive control }\end{array}$ & 260.7 & $82 \%$ & $76 \%$ & $25 \%$ & $17 \%$ & $22 \%$ \\
\hline 4 & 3 & $\begin{array}{l}\text { Synchronic and } 0.10 \text {-second } \\
\text { predictive control }\end{array}$ & 237.4 & $84 \%$ & $77 \%$ & $27 \%$ & $26 \%$ & $19 \%$ \\
\hline 4 & 3 & $\begin{array}{l}\text { Synchronic and } 0.10 \text {-second } \\
\text { predictive control }\end{array}$ & 193.4 & $83 \%$ & $76 \%$ & $21 \%$ & $17 \%$ & $26 \%$ \\
\hline 4 & 3 & $\begin{array}{l}\text { Synchronic and } 0.10 \text {-second } \\
\text { predictive control }\end{array}$ & 129.5 & $80 \%$ & $72 \%$ & $5 \%$ & $13 \%$ & $6 \%$ \\
\hline 4 & 3 & $\begin{array}{l}\text { Synchronic and } 0.10 \text {-second } \\
\text { predictive control }\end{array}$ & 91.4 & $81 \%$ & $71 \%$ & $18 \%$ & $14 \%$ & $12 \%$ \\
\hline 4 & 3 & $\begin{array}{l}\text { Synchronic and } 0.10 \text {-second } \\
\text { predictive control }\end{array}$ & 43.5 & $74 \%$ & $75 \%$ & $14 \%$ & $-4 \%$ & $-18 \%$ \\
\hline
\end{tabular}

Although the acceleration response of the test structure at the 1st floor increased to almost equal those of passive control, the acceleration control at the 2 nd floor and base shear control are superior to those of passive control. The test results in Table 5 show that the shock absorption ratios of displacement of the test structure under asynchronous control with predictive control of 0.07 seconds are greater than $42 \%$, superior to those under passive control. Although the acceleration response of the test structure at the 1st and 2nd floors and the base shear responses of the test structure increased, the control effects are superior to those of passive control.

(3) Synchronous Switching at Different Floors. Table 4 reveals that the shock absorption ratios of displacement of the test structure under synchronous control with predictive control of 0.10 seconds at the 1 st floor are greater than $50 \%$. Although the base shear responses of the test structure are effectively controlled under this condition, the acceleration responses at the 1st floor increased. The shock absorption ratios of displacement of the test structure under synchronous control with predictive control of 0.10 seconds at the 2 nd floor are greater than $35 \%$. However, the acceleration responses at the 1st and 2nd floors and the base shear responses of the test structure under this control condition increased; these results are worse than those of passive control. The test results in Table 5 show that, for synchronous control with predictive control of 0.10 seconds at the 1st floor, the average shock absorption ratios of displacement of the test structure are $54.67 \%$ at the 1 st floor and $44 \%$ at the 2 nd floor. Nevertheless, the acceleration responses increased at the 1st and 2nd floors, as did base shear, and the results are superior to those of passive control. For synchronous control with predictive control of 0.10 seconds at the 2 nd floor, the shock absorption ratios of displacement of the test structure are greater than
$24 \%$. However, the acceleration responses at the 1st and 2 nd floors and the base shear responses of the test structure under this control condition increased, and these results are worse than those of passive control.

When the structural control capability is insufficient to control the dynamic response of the test structure, the following phenomena occurred. (1) Shock absorption ratios are reduced by about 10 to $20 \%$ when only the 1 st floor is under control. The shock absorption effect is smaller at the 2nd floor than that at the 1st floor. (2) If the 2 nd floor is under control, the shock absorption effect is still smaller at the 2nd floor than at the 1st floor. Thus, if only one control set is to be used, it should be installed on a lower floor to provide better seismic proofing.

From the above descriptions, it is clear that the displacement control, acceleration control, and base shear control of the three active control methods-(1) synchronous control with predictive control of $0.13,0.10$, and 0.07 seconds, (2) synchronous control without predictive control, and (3) asynchronous control with predictive control of 0.10 secondsare superior to those of passive control. The best control effects are achieved with synchronous control with predictive control of 0.13 and 0.10 seconds.

(4) Control Effects of Various Stiffeners with Synchronous Control and Predictive Control. The control effects of 2 stiffeners ( stiffening ratio $=1.193$ ) added at the 1 st and 2 nd floors and those of 4 stiffeners (stiffening ratio $=2.338$ ) added at the 1st floor and 3 stiffeners (stiffening ratio $=1.790$ ) added at the 2nd floor with synchronous control and predictive control of 0.10 seconds under excitation of El Centro earthquake records with various peak ground acceleration rates are compared, and the displacement control effects are found to be almost the same. The acceleration control and base 
TABLE 5: The ratios of maximum shock absorption of test structure under excitation of Kobe earthquake record with various control conditions and different peak ground acceleration.

\begin{tabular}{|c|c|c|c|c|c|c|c|c|}
\hline $\begin{array}{l}\text { Number of } \\
\text { stiffeners at } \\
\text { 1st floor }\end{array}$ & $\begin{array}{l}\text { Number of } \\
\text { stiffeners at } \\
\text { 2nd floor }\end{array}$ & Control conditions & A0 & D1 & D2 & $\mathrm{A} 1$ & $\mathrm{~A} 2$ & Base shear \\
\hline 0 & 0 & $\mathrm{NC}$ & 69.3 & $0 \%$ & $0 \%$ & $0 \%$ & $0 \%$ & $0.0 \%$ \\
\hline 2 & 2 & Passive & 94.0 & $15 \%$ & $30 \%$ & $-45 \%$ & $-49 \%$ & $-112.0 \%$ \\
\hline 4 & 3 & Passive & 53.4 & $27 \%$ & $23 \%$ & $-48 \%$ & $-112 \%$ & $-164.0 \%$ \\
\hline 4 & 3 & Passive & 93.8 & $23 \%$ & $24 \%$ & $-63 \%$ & $-110 \%$ & $-185.5 \%$ \\
\hline 2 & 2 & $\begin{array}{l}\text { Synchronic and } 0.13 \text {-second } \\
\text { predictive control }\end{array}$ & 205.3 & $62 \%$ & $60 \%$ & $32 \%$ & $10 \%$ & $-10.2 \%$ \\
\hline 2 & 2 & $\begin{array}{l}\text { Synchronic and } 0.13 \text {-second } \\
\text { predictive control }\end{array}$ & 139.6 & $57 \%$ & $57 \%$ & $38 \%$ & $-1 \%$ & $-23.1 \%$ \\
\hline 2 & 2 & $\begin{array}{l}\text { Synchronic and } 0.13 \text {-second } \\
\text { predictive control }\end{array}$ & 108.2 & $62 \%$ & $66 \%$ & $46 \%$ & $18 \%$ & $-10.2 \%$ \\
\hline 2 & 2 & $\begin{array}{l}\text { Synchronic and } 0.13 \text {-second } \\
\text { predictive control }\end{array}$ & 45.8 & $54 \%$ & $62 \%$ & $25 \%$ & $9 \%$ & $-24.7 \%$ \\
\hline 2 & 2 & $\begin{array}{l}\text { Synchronic and } 0.10 \text {-second } \\
\text { predictive control }\end{array}$ & 197.3 & $61 \%$ & $59 \%$ & $29 \%$ & $-6 \%$ & $-23.1 \%$ \\
\hline 2 & 2 & $\begin{array}{l}\text { Synchronic and } 0.10 \text {-second } \\
\text { predictive control }\end{array}$ & 137.8 & $58 \%$ & $59 \%$ & $31 \%$ & $-2 \%$ & $-29.3 \%$ \\
\hline 2 & 2 & $\begin{array}{l}\text { Synchronic and } 0.10 \text {-second } \\
\text { predictive control }\end{array}$ & 94.6 & $59 \%$ & $63 \%$ & $39 \%$ & $-2 \%$ & $-17.2 \%$ \\
\hline 2 & 2 & $\begin{array}{l}\text { Synchronic and } 0.10 \text {-second } \\
\text { predictive control }\end{array}$ & 50.3 & $58 \%$ & $65 \%$ & $31 \%$ & $-1 \%$ & $-19.9 \%$ \\
\hline 2 & 2 & $\begin{array}{l}\text { Synchronic and } 0.07 \text {-second } \\
\text { predictive control }\end{array}$ & 91.9 & $32 \%$ & $45 \%$ & $0 \%$ & $-33 \%$ & $-82.1 \%$ \\
\hline 2 & 2 & $\begin{array}{l}\text { Synchronic and } 0.07 \text {-second } \\
\text { predictive control }\end{array}$ & 48.5 & $28 \%$ & $40 \%$ & $10 \%$ & $-28 \%$ & $-76.1 \%$ \\
\hline 2 & 2 & Synchronic control & 86.2 & $26 \%$ & $41 \%$ & $-6 \%$ & $-40 \%$ & $-92.4 \%$ \\
\hline 2 & 2 & Synchronic control & 43.6 & $19 \%$ & $33 \%$ & $0 \%$ & $-45 \%$ & $-98.7 \%$ \\
\hline 2 & 2 & $\begin{array}{l}\text { Asynchronic and } 0.10 \text {-second } \\
\text { predictive control }\end{array}$ & 109.9 & $42 \%$ & $54 \%$ & $-21 \%$ & $-14 \%$ & $-37.4 \%$ \\
\hline 2 & 2 & $\begin{array}{c}\text { Asynchronic and } 0.10 \text {-second } \\
\text { predictive control }\end{array}$ & 47.7 & $55 \%$ & $43 \%$ & $-34 \%$ & $-19 \%$ & $-31.7 \%$ \\
\hline 2 & 2 & $\begin{array}{l}0.10 \text {-second predictive control at } 1 \text { st } \\
\text { floor }\end{array}$ & 133.7 & $46 \%$ & $36 \%$ & $-56 \%$ & $-38 \%$ & $-46.6 \%$ \\
\hline 2 & 2 & $\begin{array}{l}0.10 \text {-second predictive control at } 1 \text { st } \\
\text { floor }\end{array}$ & 116.0 & $62 \%$ & $51 \%$ & $-12 \%$ & $-11 \%$ & $-10.0 \%$ \\
\hline 2 & 2 & $\begin{array}{l}0.10 \text {-second predictive control at 1st } \\
\text { floor }\end{array}$ & 48.2 & $56 \%$ & $45 \%$ & $-37 \%$ & $-24 \%$ & $-26.9 \%$ \\
\hline 2 & 2 & $\begin{array}{l}0.10 \text {-second predictive control at } \\
\text { 2nd floor }\end{array}$ & 91.7 & $24 \%$ & $28 \%$ & $-101 \%$ & $-69 \%$ & $-120.2 \%$ \\
\hline 2 & 2 & $\begin{array}{l}0.10 \text {-second predictive control at } \\
\text { 2nd floor }\end{array}$ & 48.9 & $26 \%$ & $28 \%$ & $-78 \%$ & $-74 \%$ & $-90.9 \%$ \\
\hline 4 & 3 & $\begin{array}{l}\text { Synchronic and } 0.10 \text {-second } \\
\text { predictive control }\end{array}$ & 237.5 & $73 \%$ & $74 \%$ & $44 \%$ & $24 \%$ & $-2.1 \%$ \\
\hline 4 & 3 & $\begin{array}{l}\text { Synchronic and } 0.10 \text {-second } \\
\text { predictive control }\end{array}$ & 175.2 & $71 \%$ & $72 \%$ & $41 \%$ & $17 \%$ & $-14.7 \%$ \\
\hline 4 & 3 & $\begin{array}{l}\text { Synchronic and } 0.10 \text {-second } \\
\text { predictive control }\end{array}$ & 135.5 & $73 \%$ & $71 \%$ & $45 \%$ & $17 \%$ & $-12.5 \%$ \\
\hline 4 & 3 & $\begin{array}{l}\text { Synchronic and } 0.10 \text {-second } \\
\text { predictive control }\end{array}$ & 92.5 & $76 \%$ & $72 \%$ & $43 \%$ & $22 \%$ & $-1.2 \%$ \\
\hline 4 & 3 & $\begin{array}{l}\text { Synchronic and } 0.10 \text {-second } \\
\text { predictive control }\end{array}$ & 51.5 & $74 \%$ & $73 \%$ & $42 \%$ & $-21 \%$ & $14.2 \%$ \\
\hline
\end{tabular}


shear control are lower with higher stiffening ratios than with lower stiffening ratios. However, the control effects of these two control methods achieve an acceptable seismic proofing capability. In contrast, the control effects of these two control methods with synchronous control and predictive control of 0.10 seconds under excitation of the Kobe earthquake records with various peak ground acceleration rates show that the displacement control and acceleration control effects are higher with higher stiffening ratios than with lower stiffening ratios. Furthermore, the displacement control effects are less with asynchronous control than with synchronous control. It is clear that the asynchronous switching caused an interaction phenomenon. Regarding the structural response to acceleration, large discrepancies are found in the shock absorption effects of the various structural control methods. The structural responses to acceleration are increased by the passive control method, with acceleration increasing by up to $80 \%$. The structural responses to acceleration increased under the bad control conditions of the test structure, as can be seen from Table 4 . Base shear is increased by passive stiffening of the structure but not by the proposed control method. These results indicate that the proposed control method is suitable for strengthening existing structures under excitation of far field earthquakes. The test results in Table 5 show that the structural control effects of displacement for near fault effects were similar to those of far field effects. Nevertheless, most of the acceleration and base shear responses of the test structure under excitation of the Kobe earthquake increased, in some cases by up to $100 \%$. These results reveal that the parameters of structural control of this proposed method should be designed carefully to avoid countereffects.

4.2. Influence of Prediction Time on Control Effect of the Proposed AIC. The predictive time control method is intended to predict a transient time for the time delay problem of the proposed AIC. If the device has no predictive reaction, the AIC device response for velocity is too slow to switch at the optimal time, and the control effect of this device will be degraded. In contrast, if the prediction time is too long, the device will become unstable. In order to investigate the influence of prediction time on the control effect of the proposed AIC, a series of AIC under passive control and active control without prediction time and with prediction times of 0.07 , 0.10 , and 0.13 seconds and an AIC device with synchronous switching are tested to determine the seismic proofing capability of the AIC device proposed in this study. The average shock absorption ratios of the test structure with various control conditions under excitation of the El Centro and Kobe earthquake records are shown in Figures 8 and 9, respectively.

The test results for the influence of prediction time on the control effect of the proposed AIC are discussed as follows.

(1) Without Predictive Control. When the test structure is under excitation of the El Centro earthquake without predictive control, the average shock absorption ratios of displacement at the 1st and 2nd floors are 67\% and 60\%, respectively. When two steel stiffeners (stiffening ratio = 1.193) are added at the 1st and 2nd floors, the average shock

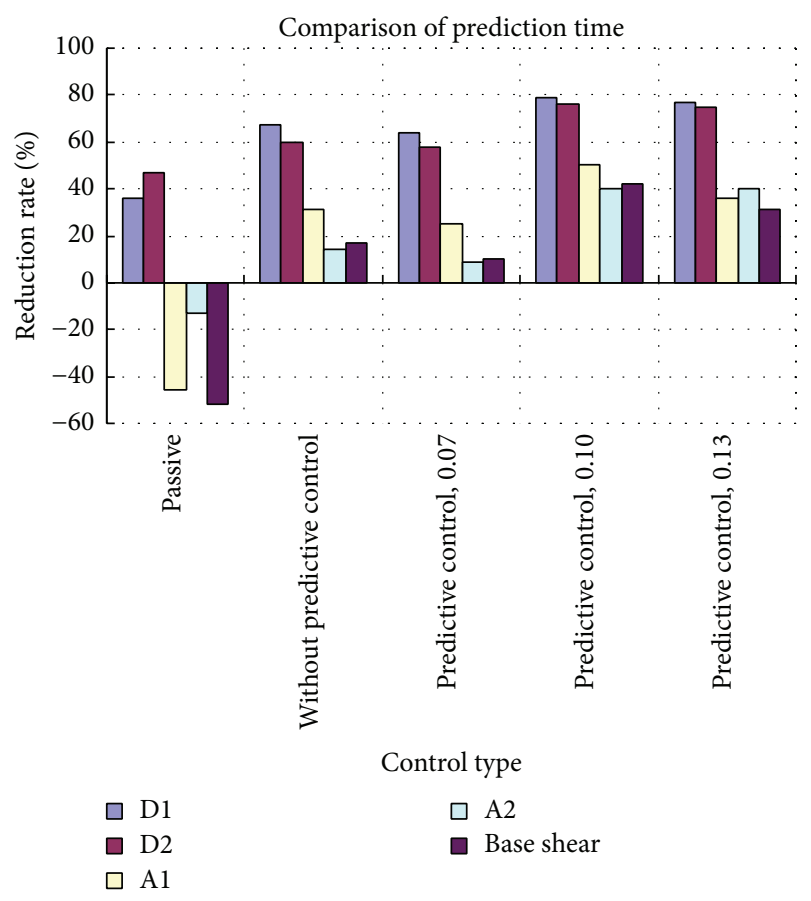

FIGURE 8: The average shock absorption ratios of the test structure with various control conditions under excitation of the El Centro earthquake.

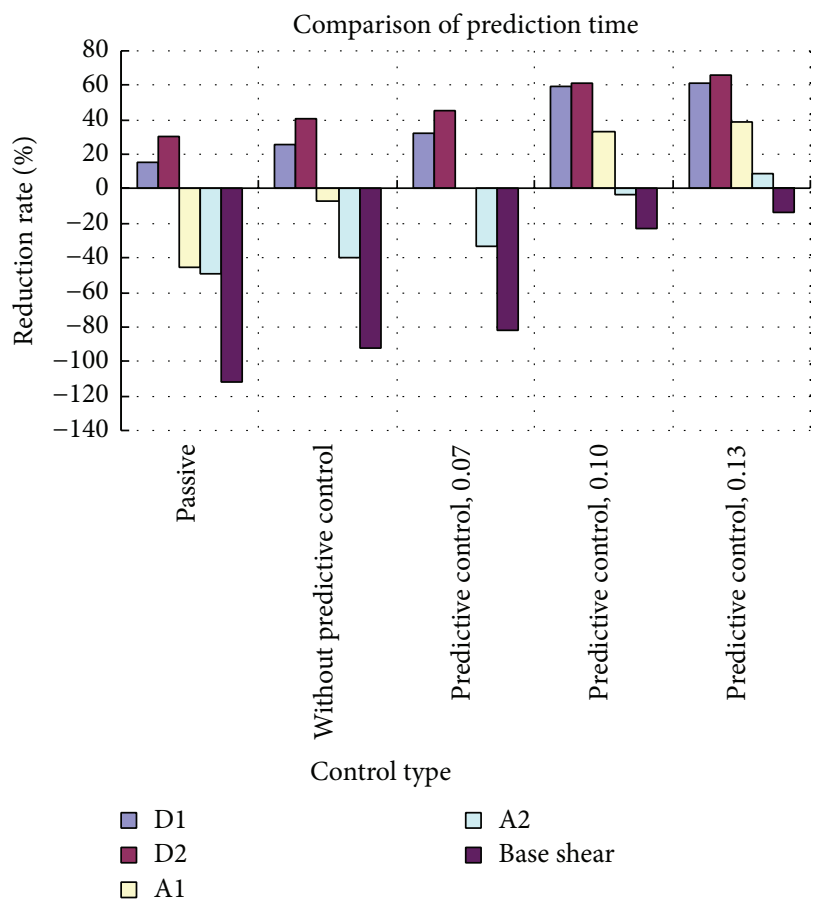

FIGURE 9: The average shock absorption ratios of the test structure with various control conditions under excitation of the Kobe earthquake.

absorption ratios of acceleration at these floors are $31 \%$ and $14 \%$, respectively. Nevertheless, the shock absorption 


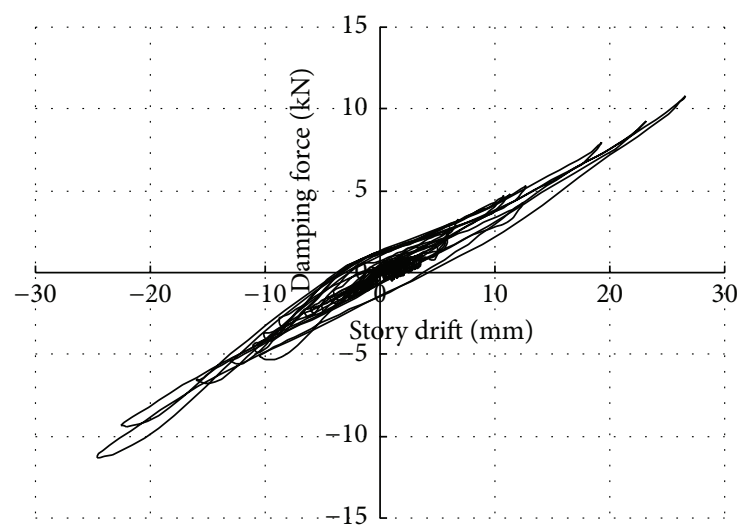

FIGURE 10: Hysteretic loop of interaction force of the test structure at the 1st floor under excitation of scaled-down Kobe earthquake with $\mathrm{PGA}=0.862 \mathrm{~m} / \mathrm{sec}^{2}$ (86.2 gal).

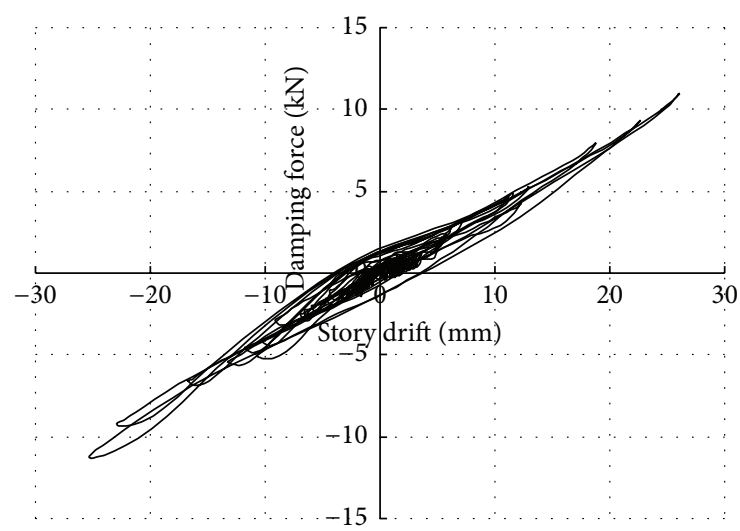

FIGURE 11: Hysteretic loop of interaction force of the test structure at the 1st floor with predictive control of 0.07 seconds under excitation of the Kobe earthquake with PGA $=0.912 \mathrm{~m} / \mathrm{sec}^{2}$ (91.2 gal).

performance of the test structure without predictive control is undesirable under excitation of the Kobe earthquake. The average shock absorption ratios of displacement are only $26 \%$ and $41 \%$ at the 1 st and 2 nd floors, respectively. These ratios are almost the same as those of passive added stiffeners. However, the shock absorption of acceleration is undesirable. The acceleration responses of the test structure increased by about $6 \%$ and $40 \%$ for the 1st and 2 nd floors, respectively, and the base shear of the test structure is amplified to $85 \%$. The reasons for these phenomena can be explained by the interaction force of the curve of force-displacement, shown in Figure 10, which presents the hysteretic loop of the interaction force at the 1st floor of the test structure under excitation of the Kobe earthquake with peak ground acceleration of $0.862 \mathrm{~m} / \mathrm{sec}^{2}$ (86.2 gal). Figure 10 shows that the area of seismic proofing is not produced significantly by the interaction force, so the seismic proofing performance is not acceptable.

(2) With a Predictive Control Time of 0.07 Seconds. The average shock absorption ratios of the test structure with this predictive control time are similar to those of the test

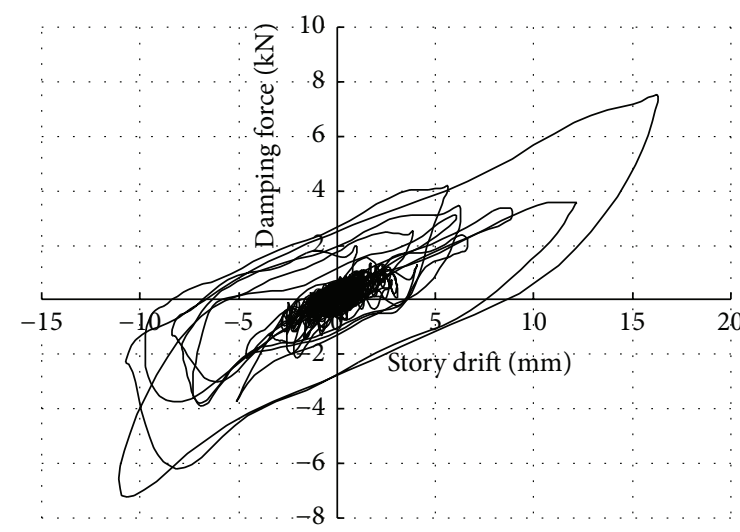

FIGURE 12: Hysteretic loop of interaction force of the test structure at the 1st floor with predictive control of 0.10 seconds under excitation of the Kobe earthquake with PGA $=0.946 \mathrm{~m} / \mathrm{sec}^{2}$ ( $94.6 \mathrm{gal}$ ).

structure without predictive control, as shown in Figure 8. In Figure 9, it can be seen that the average shock absorption ratios of the test structure under excitation of the Kobe earthquake are slightly better with predictive control than without predictive control. These results reveal that the shock absorption performance of the test structure with this prediction time is insufficient for seismic proofing of this AIC control. However, the performance with this predictive control is superior to that of passive stiffening of the structure. Figure 11 is a hysteretic loop of the interaction force at the 1st floor of the test structure with predictive control of 0.07 seconds under excitation of the Kobe earthquake with peak ground acceleration $0.912 \mathrm{~m} / \mathrm{sec}^{2}$ (91.2 gal). The area of seismic proofing is still limited by the interaction force.

(3) With a Predictive Control Time of 0.10 Seconds. The average shock absorption ratios for displacement and acceleration with a predictive control time of 0.10 seconds are greater than those without predictive control, as shown in Figure 9. In addition, the control effects of base shear suggested acceptable seismic proofing. Figure 12 is a hysteretic loop of the interaction force at the 1st floor of the test structure under excitation of the Kobe earthquake with peak ground acceleration of $0.946 \mathrm{~m} / \mathrm{sec}^{2}$ (94.6 gal). The area of shock absorption is increased by the interaction force. Therefore, the predictive control method reduced the time delay and improved the seismic proofing capability of the proposed AIC, as shown in Figure 12.

(4) With a Predictive Control Time of 0.13 Seconds. The control effects of this predictive control time are almost the same as those of the predictive control time of 0.10 seconds. The results show that the optimal predictive control time for this control method is between 0.10 seconds and 0.13 seconds.

4.3. Influence of Stiffness of the Auxiliary Structure on the Control Effect of the Proposed AIC. The control forces of the interaction system are induced earlier on the primary structure when stiffness of the auxiliary structure is greater to reduce the time delay problem. But greater stiffness 


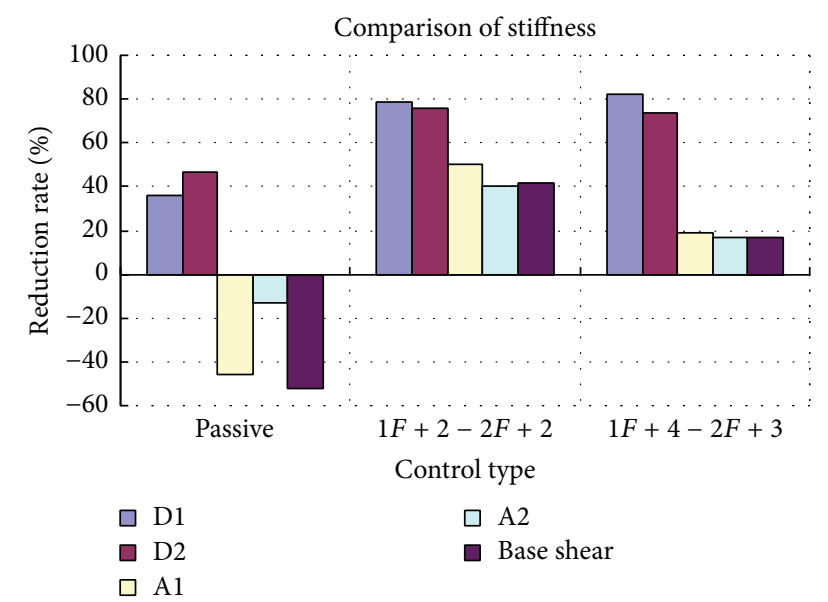

FIgURE 13: Comparison of the shock absorption ratios of the test structure under excitation of the El Centro earthquake with different control types.

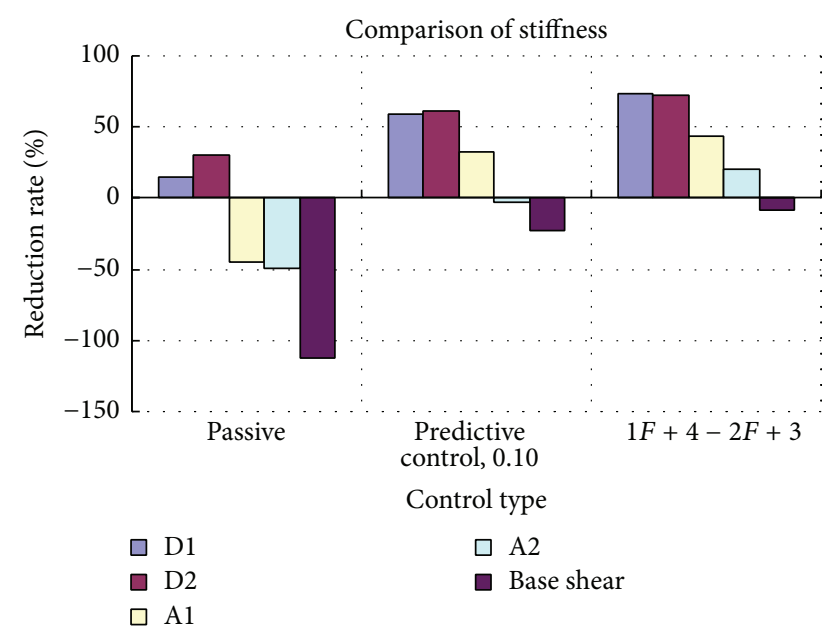

FIgURE 14: Comparison of shock absorption ratios of the test structure under excitation of the Kobe earthquake with different control types.

increased the impact force, amplified acceleration responses, and increased the base shear forces of the structure. In order to investigate the influence of the stiffness of the auxiliary structure on the control effect, two sets of shaking table tests are conducted under synchronous control with a prediction time of 0.10 -second condition to test and verify the control effects: (1) with two steel stiffeners (stiffening ratio $=1.193$ ) added at the 1st and 2nd floors and (2) with four steel stiffeners (stiffening ratio $=2.396$ ) at the 1st floor and three steel stiffeners (stiffening ratio $=1.790$ ) at the 2 nd floor. The comparisons of the shock absorption ratios of the test structure under excitation of various earthquake records are shown in Figures 13 and 14. Figure 13 shows that adding more stiffeners to the auxiliary structure does not increase the displacement control effects, but it does reduce the effects on acceleration. However, the test results in Figure 14 reveal that adding more stiffeners increased the control effects on displacement. The differences in the shock absorption ratios of displacement and acceleration with more and less stiffeners are 10 to $15 \%$ and 10 to $23 \%$, respectively. These results indicate that the stiffened structure had the characteristics of a stabilized structure under excitation of a near fault earthquake with velocity impulse action.

4.4. Influence of Synchronous Switching and Asynchronous Switching on the Control Effects of the Proposed AIC. The switching of the connection status of the auxiliary structure for each floor is dependent on the story velocity. According to the contributions of multiple modal shapes, it is difficult to reach simultaneously the switching requirements of the connection status for each floor such that there is little difference in switching between each floor. If the upper floor reaches the switching requirement, the auxiliary structure will switch first to produce the extra control force to the lower level and cause greater acceleration responses. Figure 15 presents these reactions.

If the upper level switches first, the acceleration responses of the lower level will increase suddenly, as shown in Figure 15(b). Although this situation signifies the release of internal force, it will not affect the base shear immediately. However, this phenomenon affects the follow-up signal process, causing instability of the control effects. Figure 15(c) shows that when the lower level switches first, the upper level will be affected, but when the upper level switches first, the lower level will not be affected. Nevertheless, the acceleration of the lower level will switch suddenly to cause the mass of the 1st floor to move in the right direction. The control signal is in a state of chaos and cannot deduce the control effect. In order to prevent the abovementioned phenomenon, a rule for a synchronous control method is proposed in this study. The sum of the story velocity of each floor is the total velocity of the test building for judging the direction of the interaction force, which should be opposite to the direction of the total velocity. This test is intended to investigate the high frequency responses of the test structure under the control of the synchronous control method. The test results are listed in Tables $2-5$. The average shock absorption ratios of the test structure under the control of the synchronous and asynchronous control methods are presented in Figures 16 and 17, respectively.

Figures 16 and 17 show that the structural response to displacement of the test structure is controlled well by asynchronous control. The average shock absorption ratios of displacement are about 50-60\%. However, the average shock absorption ratios of the displacement differences between these two control methods are 10 to $20 \%$. This result reveals clearly that the control effects of the synchronous control method are superior to those of the asynchronous control method. With regard to acceleration control, the structural responses to acceleration are amplified by the asynchronous control method and reduced by the synchronous control method. The variations in acceleration of these results are the same as those in Figures 13 and 14. Therefore, since the synchronous control method does not amplify the structural responses to acceleration, no high frequency responses of the test structure are induced under the control of the synchronous control method. 


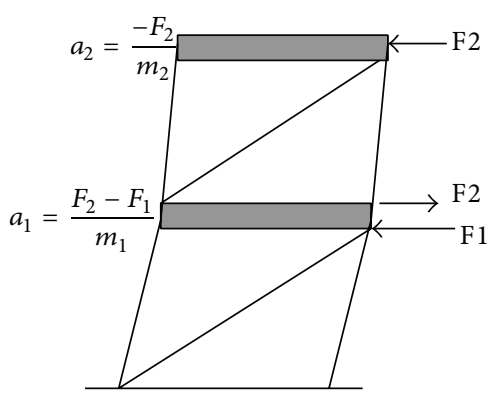

(a) Before switching

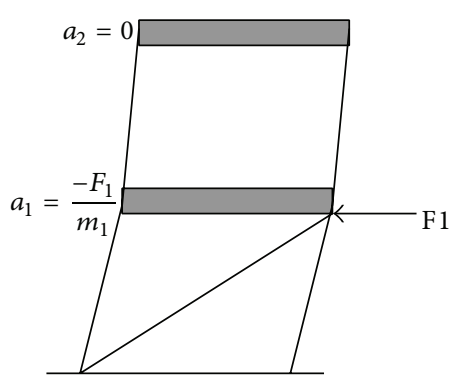

(b) After switching at 2nd floor

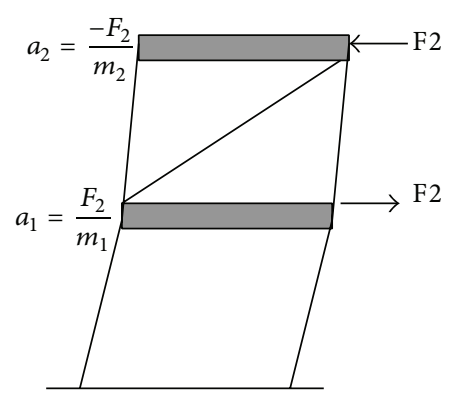

(c) After switching at 1st floor

FIGURE 15: The reasons for inducing extra acceleration response of test structure with asynchronous switch.

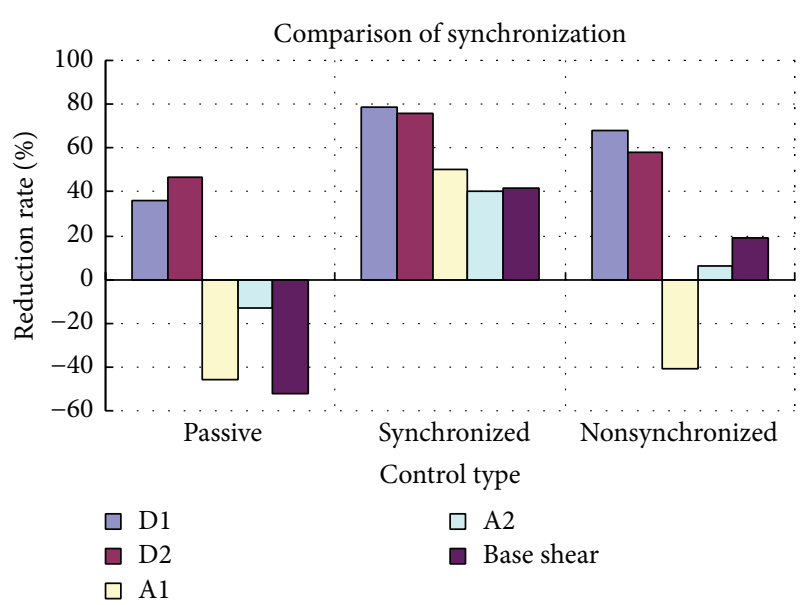

FIGURE 16: Comparison of shock absorption ratios of the test structure with synchronous and asynchronous control under excitation of the El Centro earthquake.

4.5. Influence of Control Locations of the Test Structure on the Control Effects of the Proposed AIC. In order to find the optimal place and right quantity to install this kind of device, a series of tests are planned. In this study, the shock absorption ratios of passive control, full control, control at the 1st floor, and control at the 2nd floor are investigated with a structure having a stiffening ratio of 1.193, synchronous control, and predictive control of 0.10 seconds. The test results for the average shock absorption ratios of the test structure under various control conditions are shown in Figures 18 and 19.

Figures 18 and 19 show that the control effects of the test structure with critically inadequate devices are greatly reduced. Comparison of the average shock absorption ratios of the displacement responses of the test structure with full control and that with control with fixed type stiffeners at the 1 st and 2 nd floors revealed decreases of about 10 to $20 \%$ and 35 to $45 \%$, respectively. The shock absorption ratios of displacement with full control and with control with fixed type stiffeners at the 1st floor are superior to those of passive control. Although the structural responses of displacement at the 1st floor are diminished by the control with fixed type stiffeners at the 2nd floor, they are still superior to

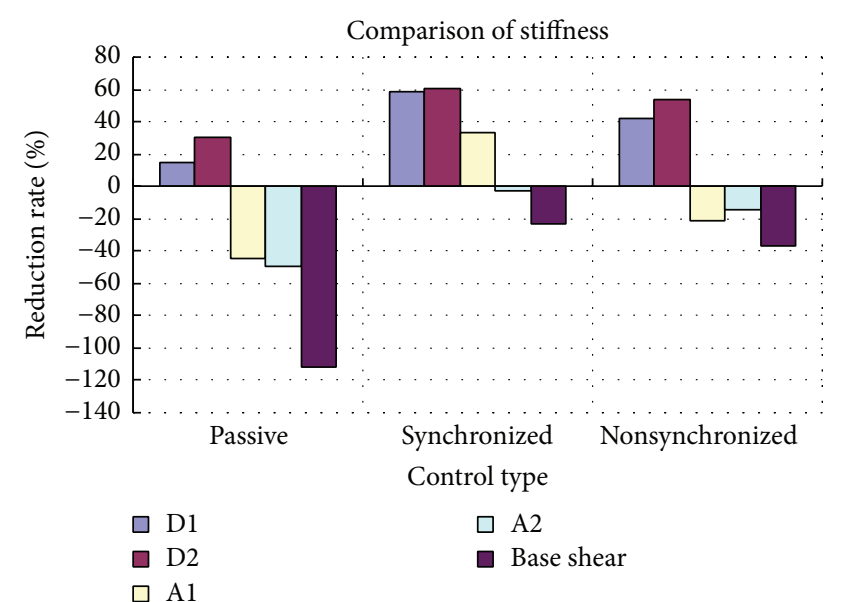

FIGURE 17: Comparison of shock absorption ratios of the test structure with synchronous and asynchronous control under excitation of the Kobe earthquake.

those of passive control, but the shock absorption ratios of displacement at the 2nd floor are lower than those of passive control. Furthermore, the story drift at the 1st floor is comparable to that at the 2 nd floor, and the average shock absorption ratios at the 1st floor are twice as large as those of passive control. However, the average shock absorption ratios at the 2 nd floor are less than those at the 1st floor. Regarding acceleration control, the structural responses to acceleration are amplified at the 1st floor such that they are even larger than those of passive control. According to the master control motion responses of the high frequency mode, although the displacement responses are reduced by this control type, the acceleration responses increased. The displacement responses with control at the 2 nd floor and fixed stiffeners at the 1st floor are nonshowable characters of control effects, which are almost the same as those of passive control. Nevertheless, with control at the 2nd floor, the structural responses to acceleration and base shear are greater than those of passive control; these phenomena could be harmful to the structure. Therefore, the best control condition for the structure is full control and the second best is control at the first floor. 


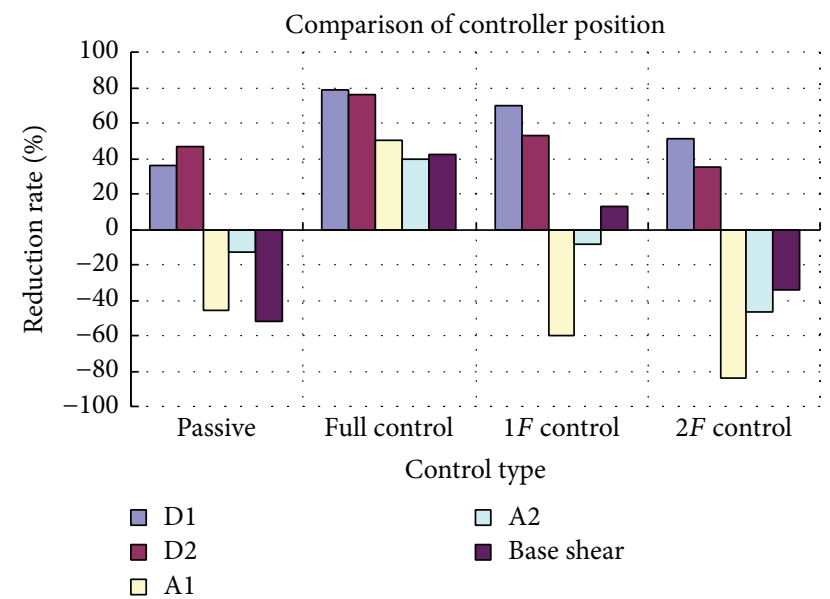

Figure 18: Comparison of shock absorption ratios of the test structure with different control types under excitation of the El Centro earthquake.

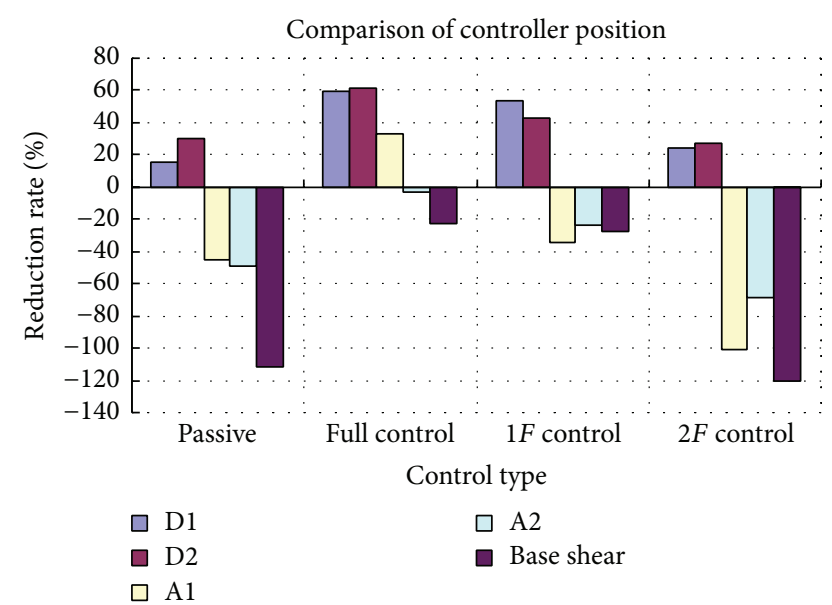

FIGURE 19: Comparison of shock absorption ratios of the test structure with different control types under excitation of the Kobe earthquake.

\section{Conclusions}

An Active Interaction Control (AIC) system was proposed by Iwan [10-15]. In this study, the Accumulated Semiactive Hydraulic Damper (ASHD) proposed by Shih et al. [16-18] is converted to a Hydraulic Interaction Element (IE) based on the energy-dissipating function of the ASHD. Then the dynamic equilibrium equation of motion for the systematic organization of the ASHD as the AIC is derived from the unlocked status and the locked status of the interactive IE. In order to improve the seismic proofing capability of this proposed new AIC, a predictive control method $[19,20]$ is applied to improve the energy-dissipating defects of the ASHD. Then, to test and verify the seismic proofing capability of the proposed AIC with and without predictive control, a full-scale two-story one-bay steel structure is tested on a shaking table in multiple forms, namely, the bare structure and the structure with various stiffeners added at different floors and with passive control, synchronous control, and asynchronous control and also with or without predictive control, under excitation of the El Centro and Kobe earthquake records with various peak ground acceleration rates. The maximum shock absorption effects of the test structure under excitation of various earthquake records and the influences on the control effects of the prediction time, stiffness of the auxiliary structure, synchronous and asynchronous switching, and control positions of the proposed AIC are discussed. The conclusions from a series of laboratory test results are summarized as follows:

(1) All of the control methods, applied in this research, provide shock absorption effects of displacement. The shock absorption effects of displacement for the test structure under the control of synchronous switching with predictive control greatly reduce the displacement of the structure. Nevertheless, the structural responses to acceleration and base shear are increased by this device under passive control. However, these structural responses are not increased by the proposed AIC device with synchronous control and a suitable prediction time.

(2) The control effects of the test structure with the proposed AIC under active control without prediction time are poor because the response to structural velocity does not provide sufficient time for the AIC device to switch at the optimal time. The area of the hysteretic loop increased when the AIC is under active control and had proper prediction time. Therefore, the seismic proofing capability of displacement and acceleration control of the test structure with this AIC under active control with proper prediction time could be increased. Test results show that, for the test structure under the control of the proposed AIC with synchronous control and predictive control of $0.10 \sim 0.13$ seconds, the shock absorption ratios of displacement are greater than $71 \%$, the average acceleration reduction ratios are $36.2 \%$ and $36.9 \%$ at the 1st and 2nd floors, respectively, and the average base shear reduction ratio is $29.6 \%$.

(3) The time delay defects of the AIC control forces, induced from the interaction element to the primary structure, are reduced by the stiffness of the auxiliary structure. The test results show that adding more stiffeners to the auxiliary structure could provide the characteristics of a stabilized structure under excitation of a near fault earthquake with velocity impulse action.

(4) The connection statuses of the auxiliary structures for each floor with simultaneous switching are hard to attain because they are dependent on the velocity of each floor. To prevent these phenomena, a rule for the synchronous control method is proposed. The test results reveal that the structural responses of displacement and acceleration control are controlled well by this proposed control method, which does not amplify the structural responses to acceleration. 
(5) The test results for the influence of the control positions of the AIC in the structure show that full control of the structure provides the best shock absorption effects, and control at the first floor is the second best option.

In this study, the ASHD is converted to AIC and predictive control methods with synchronous control are proposed to improve the seismic proofing capability of the proposed AIC. A full-scale two-story single-bay steel frame is tested on a shaking table to verify the energy-dissipating capability of this proposed device. All of the test results show that the proposed AIC with suitable stiffeners for the auxiliary structure at each floor and synchronous control and predictive control provide high reliability and practicability for improving the seismic proofing capability of a building under excitation by external forces.

\section{Appendix}

\section{A. The Detailed Derivation of This Predictive Control Method}

A.1. Noise Estimation [19, 20]. If the function of displacement corresponding to time has $M-1$ terms in variety of polynomials, it can be written as

$$
\widehat{x}(t)=\sum_{j=0}^{M-1} a_{j} t^{j},
$$

where $\hat{x}(t)$ is defined as the regression displacement, by taking a dynamic sample of a fixed frequency from relative displacements of $N$ structures, the sampling data is $x_{i}, i=$ $0 \rightarrow N-1$, where $x_{i}$ represents the displacement backward to $i$ steps from current time step, $x_{0}$ is current displacement, and $a_{j}$ is the coefficient of the $j$ th term.

According to the least square regression, the optimal estimation of polynomial coefficient in (A.1) is

$$
\{a\}=\left[E^{-1}\right]\{y\},
$$

where $\{a\}$ is a coefficient vector in $M$ dimension, $\left[E^{-1}\right]$ represents $M$ by $M$ system matrix, and $\{y\}$ determines the $M$ dimensional vector of sampling data:

$$
[E]=\left[\begin{array}{ccccc}
N & \sum_{i=0}^{N-1} i & \sum_{i=0}^{N-1} i^{2} & \ldots & \sum_{i=0}^{N-1} i^{M-1} \\
\sum_{i=0}^{N-1} i^{2} & \sum_{i=0}^{N-1} i^{3} & \ldots & \sum_{i=0}^{N-1} i^{M} \\
& \sum_{i=0}^{N-1} i^{4} & \ldots & \sum_{i=0}^{N-1} i^{M+1} \\
& & & \\
& & & \\
& & & \\
& & & \sum_{i=0}^{N-1} i^{2 M-2}
\end{array}\right],
$$

$$
\{y\}=\left\{\begin{array}{c}
\sum_{i=0}^{N-1} x_{i} \\
\sum_{i=0}^{N-1} i \cdot x_{i} \\
\sum_{i=0}^{N-1} i^{2} \cdot x_{i} \\
\vdots \\
\sum_{i=0}^{N-1} i^{M-1} \cdot x_{i}
\end{array}\right\}
$$

Practically, the data queue of displacement signals is stored in the signal creator as first-in-first-out (FIFO) information for executing semiactive control with the same frequency, which in general is greater than $100 \mathrm{~Hz}$. Therefore, the real-time optimal polynomial coefficient can be derived by modifying (A.4) as

$$
\{y\}=[B]_{M \times N}\{x\}_{N},
$$

where $\{x\}$ is the vector of structure displacement:

$$
[B]=\left[\begin{array}{ccccc}
1 & 1 & 1 & \cdots & 1 \\
0 & 1 & 2 & \cdots & N-1 \\
0 & 1^{2} & 2^{2} & \cdots & (N-1)^{2} \\
\vdots & \vdots & \vdots & \ddots & \vdots \\
0 & 1^{M-1} & 2^{M-1} & \cdots & (N-1)^{M-1}
\end{array}\right] .
$$

Substituting (A.5) into (A.2), the optimal coefficient matrix is expressed as

$$
\{a\}=\left[E^{-1}\right][B]\{x\} .
$$

Consequently, a new matrix of coefficient regression system $[F]$ is a constant matrix depending on the number of sampling points and regression ranks but independent of time or vector of data queue:

$$
\begin{aligned}
{[F]_{M \times N} } & =\left[E^{-1}\right]_{M \times M}[B]_{M \times N} \\
& =\left[E^{-1}\right]_{M \times M}[B]_{M \times N}\{x\}=[F]_{M \times N}\{x\} \\
& =[F]\{x\} .
\end{aligned}
$$

Furthermore, (A.8) can be substituted into (A.7) to obtain the regression value of displacement in matrix form as

$$
\widehat{x}_{i}=\left[\begin{array}{lllll}
1 & i & i^{2} & \cdots & i^{M-1}
\end{array}\right][F]\{x\} .
$$

An optimal coefficient vector $\left\{F_{i}\right\}$, stored in computer memory, estimated for the displacement at previous $i$ steps for carrying out real-time computations can be defined as

$$
\left[F_{i}^{T}\right]=\left[\begin{array}{lllll}
1 & i & i^{2} & \cdots & i^{M-1}
\end{array}\right][F] .
$$

Then, the optimal displacement $\widehat{x}_{i}=\left\{F_{i}\right\} \cdot\{x\}$ can be estimated based on this equation. 
A.2. Velocity Estimation [19, 20]. The optimal displacements can be easily predicted using $\hat{x}_{i}=\left\{F_{i}\right\} \cdot\{x\}$. Meanwhile, the velocity can be obtained by differentiating the displacement equation with respect to time as

$$
\dot{\hat{x}}_{i}=\frac{d}{d t} \widehat{x}(t), \quad t=i \cdot \Delta t .
$$

Therefore, (A.11) can be rewritten as

$$
\dot{\hat{x}}_{i}=\frac{\left((d / d t)\left\{F_{i}\right\} \cdot\{x\}\right)}{\Delta t} .
$$

Substituting (A.10) into (A.12), this equation can be expressed as

$$
\dot{\hat{x}}_{i}=\left\{G_{i}\right\} \cdot\{x\}
$$

where $\left\{G_{i}\right\}$ is the optimal vector of estimation velocity.

And

$$
\left[G^{T}\right]=\left[\begin{array}{llllll}
0 & 1 & 2 i & 3 i^{2} & \cdots & (M-1) i^{M-2}
\end{array}\right][F] .
$$

$\left\{G_{i}\right\}$ can be stored in computer memory for predicting the real-time velocity or regressing velocity at any arbitrary time step; that is, the optimal velocity for previous $i$ time steps from the current time can be estimated by multiplying $\left\{G_{i}\right\}$ with the derivative of the displacement vector shown as (A.12).

\section{B. Test Results of Test Structure under Excitation of Various Earthquake Records with Various Control Conditions}

See Tables 2 and 3.

\section{Competing Interests}

The authors declare that there is no conflict of interests regarding the publication of this paper.

\section{Acknowledgments}

The authors would like to acknowledge the support of Taiwan Ministry of Science and Technology through Grant nos. MOST-103-2625-M-260-001 and MOST-103-2625-M167-001.

\section{References}

[1] L. L. Chung, R. C. Lin, T. T. Soong, and A. M. Reinhorn, "Experimental study of active control for MDOF seismic structures," Journal of Engineering Mechanics, vol. 115, no. 8, pp. 1609-1627, 1989.

[2] T. T. Soong, A. M. Reinhorn, Y. P. Wang, and R. C. Lin, "Fullscale implementation of active control I: design and simulation," Journal of Structural Engineering, vol. 117, no. 11, pp. 3516-3536, 1991.

[3] A. M. Reinhorn, T. T. Soong, M. A. Riley, R. C. Lin, S. Aizawa, and M. Higashino, "Full-scale implementation of active control. II: installation and performance," Journal of Structural Engineering, vol. 119, no. 6, pp. 1935-1960, 1993.
[4] S. J. Dyke, B. F. Spencer Jr., P. Quast, M. K. Sain, D. C. Kaspari Jr., and T. T. Soong, "Acceleration feedback control of MDOF structures," Journal of Engineering Mechanics, vol. 122, no. 9, pp. 907-918, 1996.

[5] M. D. Symans and M. C. Constantinou, "Seismic testing of a building structure with a semi-active fluid damper control system," Earthquake Engineering and Structural Dynamics, vol. 26, no. 7, pp. 759-777, 1997.

[6] G. J. Hiemenz, Y. T. Choi, and N. M. Wereley, "Seismic control of civil structures utilizing semi-active MR braces," ComputerAided Civil and Infrastructure Engineering, vol. 18, no. 1, pp. 3144, 2003.

[7] V. Gattulli, M. Lepidi, and F. Potenza, "Seismic protection of frame structures via semi-active control: modeling and implementation issues," Earthquake Engineering and Engineering Vibration, vol. 8, no. 4, pp. 627-645, 2010.

[8] N. Caterino, M. Spizzuoco, J. M. Londoño, and A. Occhiuzzi, "Experimental issues in testing a semiactive technique to control earthquake induced vibration," Modelling and Simulation in Engineering, vol. 2014, Article ID 535434, 11 pages, 2014.

[9] S. Pourzeynali and P. Jooei, "Semi-active control of building structures using variable stiffness device and fuzzy logic," International Journal of Engineering, Transactions A: Basics, vol. 26, no. 10, pp. 1169-1182, 2013.

[10] K. Hiramoto, T. Matsuoka, and K. Sunakoda, "Simultaneous optimal design of the structural model for the semi-active control design and the model-based semi-active control," Structural Control and Health Monitoring, vol. 21, no. 4, pp. 522-541, 2014.

[11] W. D. Iwan and L. J. Wang, "New developments in active interaction control," in Proceedings of the 2nd International Workshop on Structural Control, Hong Kong, 1996.

[12] L. J. Wang, "Active interaction control for civil structures," Tech. Rep. CaltechEERL:1997.EERL-97-04, California Institute of Technology, 1997.

[13] Y. Zhang and W. D. Iwan, "Active interaction control of tall buildings subjected to near-field ground motions," Journal of Structural Engineering, vol. 128, no. 1, pp. 69-79, 2002.

[14] Y. Zhang and W. D. Iwan, "Active interaction control of civil structures-part 1: SDOF systems," Earthquake Engineering and Structural Dynamics, vol. 31, no. 1, pp. 161-178, 2002.

[15] Y. Zhang and W. D. Iwan, "Active interaction control of civil structures. Part 2: MDOF systems," Earthquake Engineering \& Structural Dynamics, vol. 31, no. 1, pp. 179-194, 2002.

[16] M.-H. Shih and W.-P. Sung, "Development of semi-active hydraulic damper as active interaction control device to withstand external excitation," Sadhana, vol. 39, no. 1, pp. 123-138, 2014.

[17] M.-H. Shih, W.-P. Sung, and C. G. Go, "Development of accumulated semi-active hydraulic damper," Experimental Techniques, vol. 26, no. 5, pp. 29-32, 2002.

[18] M.-H. Shih, C.-I. Lin, and W.-P. Sung, "Numerical analysis for shock absorption performance of accumulated semi-active hydraulic damper," Journal of Dynamical Systems \& Geometric Theories, vol. 4, no. 1, pp. 29-45, 2006.

[19] M.-H. Shih, W.-P. Sung, and C.-J. Wang, "A model for signal processing and predictive control of semi-active structural control system," Sadhana-Academy Proceedings in Engineering Sciences, vol. 34, part 3, pp. 421-437, 2009.

[20] M.-H. Shih and W.-P. Sung, "Predictive control and signal on noise reduction for semi-active hydraulic damper," International Journal of Structural Stability and Dynamics, vol. 7, no. 1, pp. 129-149, 2007. 


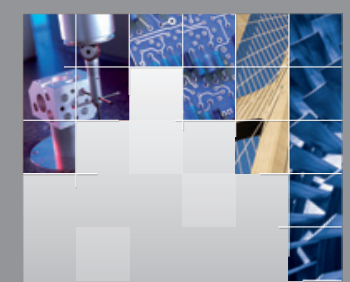

\section{Enfincering}
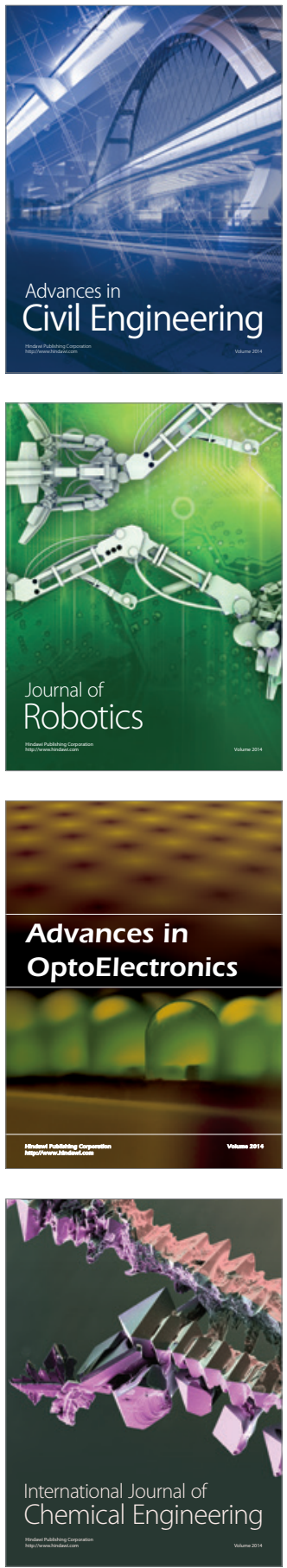

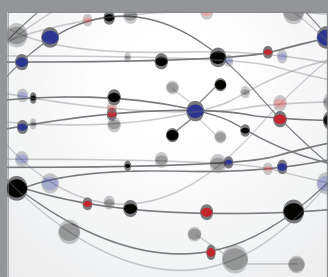

The Scientific World Journal

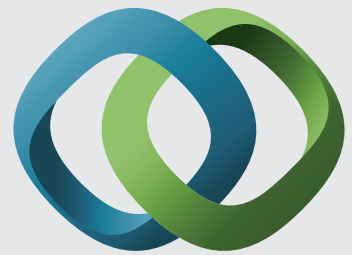

\section{Hindawi}

Submit your manuscripts at

http://www.hindawi.com
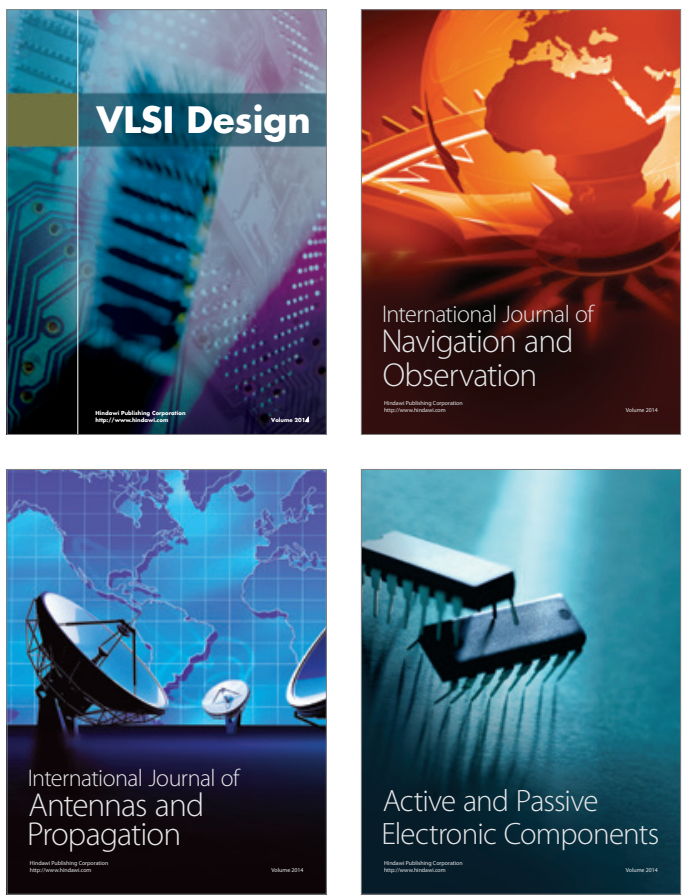
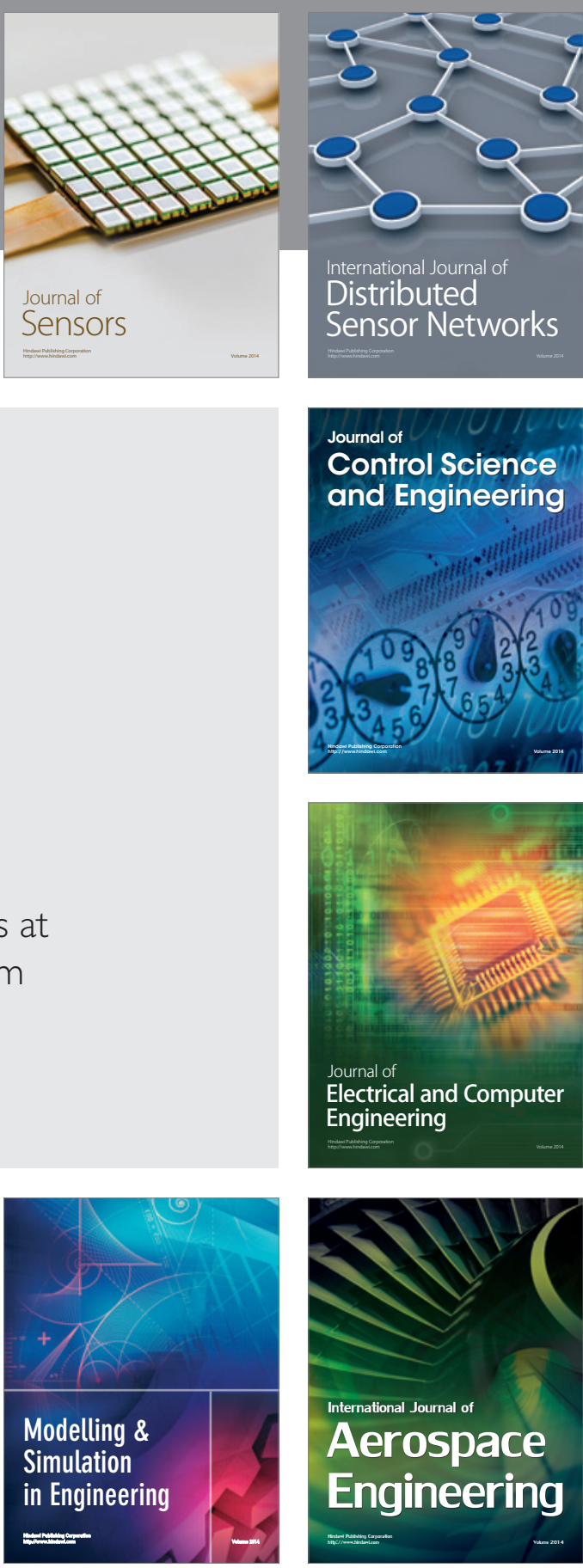

International Journal of

Distributed

Sensor Networks

Journal of

Control Science

and Engineering
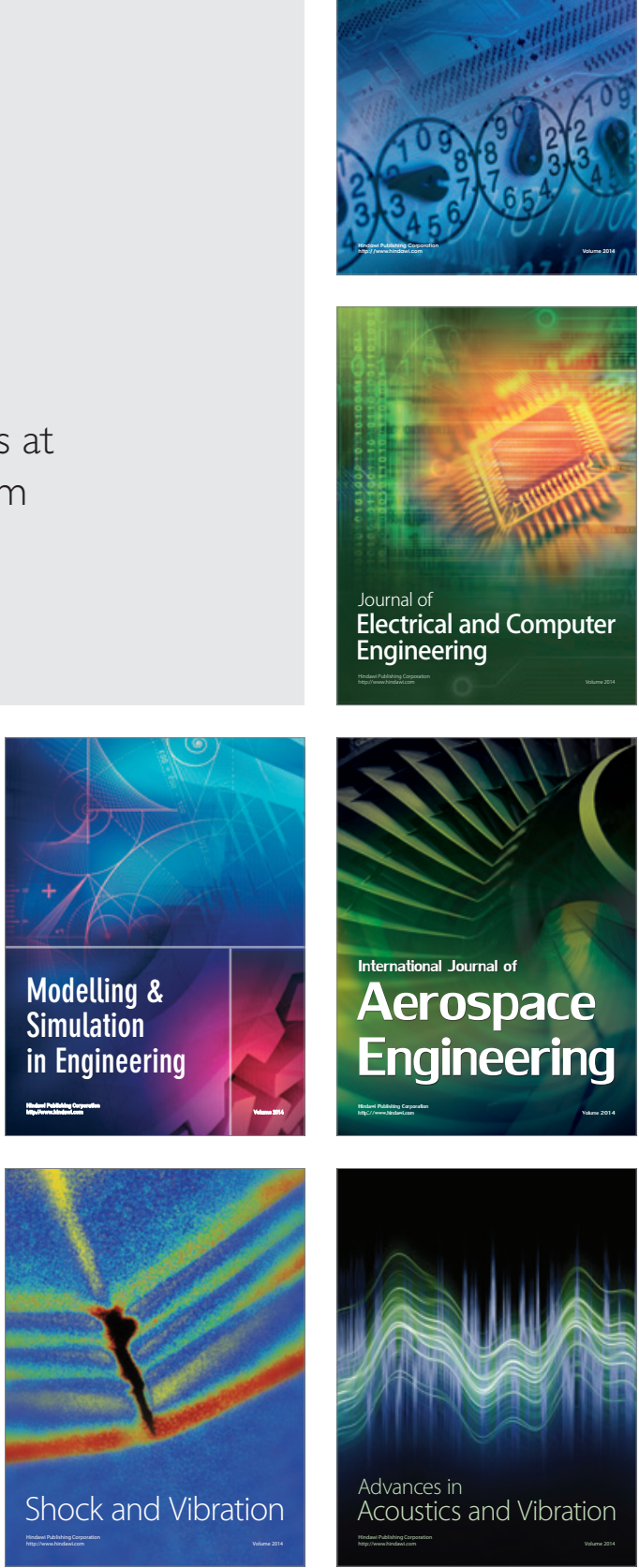